\title{
Retrieving tropospheric nitrogen dioxide from the Ozone Monitoring Instrument: effects of aerosols, surface reflectance anisotropy, and vertical profile of nitrogen dioxide
}

\author{
J.-T. Lin ${ }^{1}$, R. V. Martin ${ }^{2,3}$, K. F. Boersma ${ }^{4,5}$, M. Sneep ${ }^{4}$, P. Stammes ${ }^{4}$, R. Spurr ${ }^{6}$, P. Wang ${ }^{7}$, M. Van Roozendael ${ }^{8}$, \\ K. Clémer ${ }^{9}$, and H. Irie ${ }^{10}$ \\ ${ }^{1}$ Laboratory for Climate and Ocean-Atmosphere Studies, Department of Atmospheric and Oceanic Sciences, School of \\ Physics, Peking University, Beijing 100871, China \\ ${ }^{2}$ Department of Physics and Atmospheric Science, Dalhousie University, Halifax, Nova Scotia, Canada \\ ${ }^{3}$ Atomic and Molecular Physics Division, Harvard-Smithsonian Center for Astrophysics, Cambridge, Massachusetts, USA \\ ${ }^{4}$ Royal Netherlands Meteorological Institute, De Bilt, the Netherlands \\ ${ }^{5}$ Fluid Dynamics Lab, Eindhoven University of Technology, Eindhoven, the Netherlands \\ ${ }^{6}$ RT Solutions Inc., Cambridge, Massachusetts 02138, USA \\ ${ }^{7}$ IAP/CAS, Institute of Atmospheric Physics, Chinese Academy of Sciences, Beijing, China \\ ${ }^{8}$ BIRA-IASB, Belgian Institute for Space Aeronomy, Brussels, Belgium \\ ${ }^{9}$ Instituut voor sterrenkunde, KU Leuven, Celestijnenlaan 200D, 3001 Heverlee, Belgium \\ ${ }^{10}$ Center for Environmental Remote Sensing, Chiba University, 1-33 Yayoicho, Inage-ku, Chiba 263-8522, Japan
}

Correspondence to: J.-T. Lin (linjt@pku.edu.cn)

Received: 2 July 2013 - Published in Atmos. Chem. Phys. Discuss.: 14 August 2013

Revised: 18 December 2013 - Accepted: 7 January 2014 - Published: 7 February 2014

\begin{abstract}
Retrievals of tropospheric nitrogen dioxide $\left(\mathrm{NO}_{2}\right)$ from the Ozone Monitoring Instrument (OMI) are subject to errors in the treatments of aerosols, surface reflectance anisotropy, and vertical profile of $\mathrm{NO}_{2}$. Here we quantify the influences over China via an improved retrieval process. We explicitly account for aerosol optical effects (simulated by nested GEOS-Chem at $0.667^{\circ}$ long. $\times 0.5^{\circ}$ lat. and constrained by aerosol measurements), surface reflectance anisotropy, and high-resolution vertical profiles of $\mathrm{NO}_{2}$ (simulated by GEOS-Chem). Prior to the $\mathrm{NO}_{2}$ retrieval, we derive the cloud information using consistent ancillary assumptions.

We compare our retrieval to the widely used DOMINO v2 product, using MAX-DOAS measurements at three urban/suburban sites in East China as reference and focusing the analysis on the 127 OMI pixels (in 30 days) closest to the MAX-DOAS sites. We find that our retrieval reduces the interference of aerosols on the retrieved cloud properties, thus enhancing the number of valid OMI pixels by about $25 \%$. Compared to DOMINO v2, our retrieval better captures the day-to-day variability in MAX-DOAS $\mathrm{NO}_{2}$ data
\end{abstract}

$\left(R^{2}=0.96\right.$ versus 0.72$)$, due to pixel-specific radiative transfer calculations rather than the use of a look-up table, explicit inclusion of aerosols, and consideration of surface reflectance anisotropy. Our retrieved $\mathrm{NO}_{2}$ columns are $54 \%$ of the MAX-DOAS data on average, reflecting the inevitable spatial inconsistency between the two types of measurement, errors in MAX-DOAS data, and uncertainties in our OMI retrieval related to aerosols and vertical profile of $\mathrm{NO}_{2}$.

Sensitivity tests show that excluding aerosol optical effects can either increase or decrease the retrieved $\mathrm{NO}_{2}$ for individual OMI pixels with an average increase by $14 \%$. Excluding aerosols also complexly affects the retrievals of cloud fraction and particularly cloud pressure. Employing various surface albedo data sets slightly affects the retrieved $\mathrm{NO}_{2}$ on average (within $10 \%$ ). The retrieved $\mathrm{NO}_{2}$ columns increase when the $\mathrm{NO}_{2}$ profiles are taken from MAX-DOAS retrievals (by $19 \%$ on average) or TM4 simulations (by 13\%) instead of GEOS-Chem simulations. Our findings are also relevant to retrievals of other pollutants (e.g., sulfur dioxide, 
formaldehyde, glyoxal) from UV-visible backscatter satellite instruments.

\section{Introduction}

Vertical column densities (VCDs) of tropospheric nitrogen dioxide $\left(\mathrm{NO}_{2}\right)$ retrieved from the Ozone Monitoring Instrument (OMI) have been used extensively to analyze emissions of nitrogen oxides $\left(\mathrm{NO}_{\mathrm{x}}\right)$ from anthropogenic and/or natural sources (Hudman et al., 2010; Mebust et al., 2011; Beirle et al., 2011; Lin, 2012), including the magnitude (Zhao and Wang, 2009; Lin et al., 2010b; Mijling and van der A, 2012), trends (Lin et al., 2010a; Lamsal et al., 2011; Castellanos and Boersma, 2012; Wang et al., 2012; Zhou et al., 2012), and variability (Mijling et al., 2009; Hudman et al., 2010; Yu et al., 2010; Lin and McElroy, 2011). The $\mathrm{NO}_{2}$ retrievals have also been used to analyze $\mathrm{NO}_{\mathrm{x}}$ concentrations near the ground (Lamsal et al., 2008; Novotny et al., 2011). The retrieved changes in $\mathrm{NO}_{\mathrm{x}}$ are found to have influenced other pollution, such as aerosols (Lin et al., 2010a) and ozone (Walker et al., 2010), and have become a major concern for the atmospheric environment (Richter et al., 2005; Zhang et al., 2012).

The retrieval of tropospheric $\mathrm{NO}_{2} \mathrm{VCD}$ from $\mathrm{OMI}$ is done by dividing the tropospheric slant column density (SCD) by the tropospheric air mass factor (AMF) (Boersma et al., 2011). (Hereafter we will focus the analysis in the troposphere.) The AMF is derived by radiative transfer modeling driven by ancillary assumptions on surface reflectance (Rs), surface pressure (Ps), pressure and temperature profiles, aerosol characteristics, cloud fraction $(\mathrm{CF})$, cloud pressure (CP), and vertical profile of $\mathrm{NO}_{2}$. The calculation of AMF provides the dominant source of errors in the retrieved $\mathrm{NO}_{2}$ columns over polluted areas (Boersma et al., 2007), with important consequences on emission constraints and other applications.

Current representative OMI products covering China, DOMINO v2 (Boersma et al., 2011) and $\mathrm{OMNO}_{2}$ v2 (Bucsela et al., 2013), do not explicitly account for the effect of aerosols on the solar radiation. Rather, these retrievals assume that the cloud correction accounts for the effect of aerosols, as the OMI cloud retrieval provides effective cloud parameters sensitive to aerosol burdens (Boersma et al., 2011). Since aerosols affect the radiation field in retrieving both clouds (Boersma et al., 2011) and $\mathrm{NO}_{2}$ (Leitão et al., 2010), the net effect on the retrieved $\mathrm{NO}_{2}$ columns is unclear. This aerosol issue is particularly significant over East China due to its high aerosol loadings (Lin et al., 2010a; Cheng et al., 2013). This issue can be addressed by retrieving clouds and $\mathrm{NO}_{2}$ columns that consistently account for the effects of aerosols (e.g., Martin, 2008).

In addition, the DOMINO and $\mathrm{OMNO}_{2}$ products also assume Lambertian surface with no dependence of surface reflectance on the geometry of the light path (Boersma et al.,
2011; Bucsela et al., 2013); the retrieved $\mathrm{NO}_{2}$ VCDs are affected by $20 \%$ or less over Europe (Zhou et al., 2010). DOMINO and $\mathrm{OMNO}_{2}$ adopt the vertical profile of $\mathrm{NO}_{2}$ simulated by coarse-resolution global chemical transport models (CTMs), TM4 at $3^{\circ}$ long. $\times 2^{\circ}$ lat. for DOMINO v2 and GMI at $2.5^{\circ}$ long. $\times 2^{\circ}$ lat. for $\mathrm{OMNO}_{2} \mathrm{v} 2$, which are unable to capture the variability of $\mathrm{NO}_{2}$ at smaller scales. Russell et al. (2011) found differences in retrieved $\mathrm{NO}_{2}$ columns of $-75-10 \%$ for individual OMI pixels around California in June 2008 when adopting $\mathrm{NO}_{2}$ profiles from a WRFChem simulation at a resolution of $4 \mathrm{~km} \times 4 \mathrm{~km}$ instead of a GEOS-Chem simulation at $2.5^{\circ}$ long. $\times 2^{\circ}$ lat. Furthermore, DOMINO and $\mathrm{OMNO}_{2}$ adopt the cloud information from the OMCLDO2 cloud retrieval (Acarreta et al., 2004; Sneep et al., 2008) with consistent assumptions on reflective properties (Earth's surface and clouds are treated as Lambertian surfaces) and surface albedo (from Kleipool et al., 2008), but with differences in the assumed surface pressure (see more discussion in Sects. 2.2 and 3).

Overall, research has found potentially large errors in the $\mathrm{NO}_{2}$ products in comparison to independent measurements (Bucsela et al., 2008; Hains et al., 2010). For China, such evaluation is rare (Irie et al., 2012; Ma et al., 2013), and the effects of individual parameters have not been quantified. Since errors in one parameter may be related to (e.g., errors in surface reflectance and aerosol optical effects may be transferred to clouds) or enhanced/compensated by/for errors in another, it is necessary to account for the direct and indirect effects of various parameters together.

In this paper, we improve the retrieval of $\mathrm{NO}_{2}$ over East China upon DOMINO v2 (hereafter referred to as DOMINO2) by enhancing the assumptions on surface pressure, surface reflectance, aerosol optical effects, cloud properties, and vertical profile of $\mathrm{NO}_{2}$ together. We calculate the tropospheric AMFs independently and adopt the tropospheric SCDs from DOMINO-2. Prior to the retrieval of $\mathrm{NO}_{2}$, we derive the cloud information through the $\mathrm{O}_{2}-\mathrm{O}_{2}$ method (Acarreta et al., 2004; Sneep et al., 2008) but using improved ancillary parameters (Ps, Rs, aerosols, pressure levels, temperature profiles) consistent with our $\mathrm{NO}_{2}$ retrieval. We compare our retrieval to DOMINO-2 using as reference the ground-based MAX-DOAS measurements from three urban/suburban sites in East China in various months of 2006, 2008, 2009, and 2011. We then evaluate the effects of aerosols, surface reflectance, and vertical profile of $\mathrm{NO}_{2}$ on the retrievals of clouds and $\mathrm{NO}_{2}$ columns. Our current analysis is focused on the OMI measurements spatiotemporally associated with the MAX-DOAS data. A later study will focus on the spatial and seasonal distributions of $\mathrm{NO}_{2}$ over China (Lin et al., 2014).

Section 2 describes the $\mathrm{NO}_{2}$ products retrieved from OMI and MAX-DOAS and presents the criteria for selecting suitable OMI and MAX-DOAS measurements for comparison. Section 3 compares the ancillary parameters employed by DOMINO-2 to those by our retrieval. Section 4 evaluates DOMINO-2 and our OMI retrieval using the $\mathrm{NO}_{2}$ data 
retrieved from MAX-DOAS. Section 5 further evaluates the effects of individual ancillary parameters on the retrievals of clouds and $\mathrm{NO}_{2}$ columns from OMI through a series of sensitivity tests. Section 6 concludes this study.

\section{Retrievals of $\mathrm{NO}_{2}$ and criteria for data selection}

\subsection{MAX-DOAS measurements}

The MAX-DOAS measurements were conducted at three urban/suburban sites in East China, one at the Institute of Atmospheric Physics (IAP), Chinese Academy of Sciences (CAS) in urban Beijing, one in Xianghe County to the southeast of Beijing, and one in the city of Tai'An. Figure 1 shows the locations of these sites with respect to the $\mathrm{NO}_{2}$ columns in July 2008 retrieved from DOMINO-2. More information about the sites is described in Table 1.

The instrument operated in Beijing and Xianghe was designed at BIRA-IASB and is described extensively by Clémer et al. (2010). It is a dual-channel system composed of two thermally regulated grating spectrometers covering the ultraviolet and visible wavelength ranges $(300-390 \mathrm{~nm}$ and $400-720 \mathrm{~nm}$, respectively) by means of low-noise cooled CCD detectors. Scattered light is collected at various elevation angles within a field of view of about $0.5^{\circ}$ by a telescope mounted on a commercial sun tracker. The received light is guided to the spectrometers through depolarizing optical fiber bundles. The telescope points towards a fixed azimuth direction (north). A full MAX-DOAS scan, which requires $\sim 15 \mathrm{~min}$, comprises nine elevation angles at $2^{\circ}, 4^{\circ}, 6^{\circ}, 8^{\circ}$, $10^{\circ}, 12^{\circ}, 15^{\circ}, 30^{\circ}$, and $90^{\circ}$ (zenith).

The instrument at Tai'An employs a miniaturized ultraviolet-visible spectrometer (B\&W TEK Inc., BTC111), a single telescope, and a movable mirror. It measures scattered sunlight sequentially every $30 \mathrm{~min}$ at five elevation angles: $5^{\circ}, 10^{\circ}, 20^{\circ}, 30^{\circ}$, and $90^{\circ}$. The telescope points to a fixed azimuth direction (north). The spectral resolution is about $0.4-0.5 \mathrm{~nm}$ for the fitting window of $460-490 \mathrm{~nm}$. More information is given by Irie et al. (2008) and Irie et al. (2012).

For all sites, the VCD of $\mathrm{NO}_{2}$ is retrieved from the radiation measurements around $477 \mathrm{~nm}$. A profile approach based on an optimal estimation scheme (Rodgers, 2000) is taken that results in a companion vertical profile of $\mathrm{NO}_{2}$ (Irie et al., 2012; Hendrick et al., 2013). The vertical profile may not represent the true distribution of $\mathrm{NO}_{2}$ because there are only about 2 degrees of freedom for signal (DFS) (Hendrick et al., 2013) or less (Irie et al., 2011) from the retrieval process. Compared to space-based remote sensing, the MAX-DOAS measurements are insensitive to surface reflectance and are subject to better cloud screening. The total retrieval uncertainty on the tropospheric $\mathrm{NO}_{2}$ column has been estimated at $11 \%$ for the Beijing and Xianghe sites (Hendrick et al., 2013) and $14 \%$ for the Tai' An site (Irie et al., 2012). These

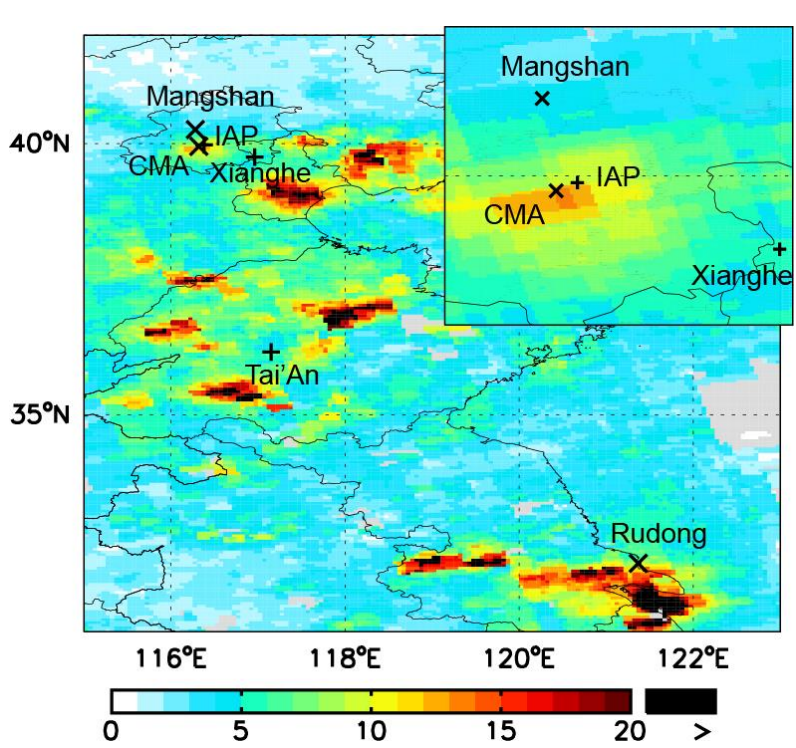

Fig. 1. Sites of MAX-DOAS measurements used in this study (Beijing IAP, Xianghe, and Tai' An: “+” signs) and in previous studies (Mangshan, Rudong (Irie et al., 2012), and Beijing CMA (Ma et al., 2013): " $x$ " signs). Overlaid on the background is the spatial distribution of $\mathrm{NO}_{2}$ columns $\left(10^{15}\right.$ molec $\mathrm{cm}^{-2}$, at $\left.0.05^{\circ}\right)$ in July 2008 retrieved by DOMINO-2 together with a zoomed-in map around Beijing $\left(116-117^{\circ} \mathrm{E}, 39.5-40.5^{\circ} \mathrm{N}\right.$; at $\left.0.01^{\circ}\right)$. OMI pixels are restricted to row-anomaly-free, ice/snow-free, $\mathrm{CRF} \leq 0.5$, and $\mathrm{VZA} \leq 30^{\circ}$.

uncertainty estimates do not account for the spatial representativeness of MAX-DOAS measurements, an important factor when comparing to satellite retrievals that cover a larger area (see Sect. 2.4.1).

Prior to the retrieval of $\mathrm{NO}_{2}$, the MAX-DOAS remote sensing data are used to derive aerosol optical depth (AOD) and aerosol extinction profile (Clémer et al., 2010; Irie et al., 2011). We employed the AOD results at the Tai' An site to constrain the respective aerosol information in retrieving clouds and $\mathrm{NO}_{2}$ columns from OMI (see Sect. 2.3). The retrieved aerosol extinction profile was not used considering its low DFS at $2.1 \pm 0.6$ (Irie et al., 2011).

\subsection{DOMINO-2}

For DOMINO-2, the AMF is interpolated from a precalculated look-up table (LUT) derived from the doubling-adding KNMI (DAK v3.0) radiative transfer model (RTM). The LUT provides layer AMFs (i.e., the sensitivity of SCD to VCD in individual atmospheric layers) that are determined by surface albedo (As), Ps, CF, CP, atmospheric pressure level, and the geometry of the light path. Table 2 summarizes the ancillary parameters used in deriving DOMINO-2.

DOMINO-2 adopts the monthly As data averaged from the OMI measurements between October 2004 and October 2007 (OMLER v1; Kleipool et al., 2008), not accounting for 
Table 1. MAX-DOAS measurements.

\begin{tabular}{llll}
\hline Location & Spatial Information & Measurement Time & Reference \\
\hline Tai' An & $117.15^{\circ} \mathrm{E}, 36.16^{\circ} \mathrm{N}, 126 \mathrm{~m}$; urban & $2006 / 05 / 30-2006 / 06 / 29$ & Irie et al. (2012) \\
IAP & $116.38^{\circ} \mathrm{E}, 39.98^{\circ} \mathrm{N}, 92 \mathrm{~m}$; urban & $2008 / 06 / 22-2009 / 04 / 16$ & Hendrick et al. (2013) \\
Xianghe & $116.96^{\circ} \mathrm{E}, 39.75^{\circ} \mathrm{N}, 36 \mathrm{~m}$; suburban & $2011 / 09 / 29-2011 / 10 / 15$ & Hendrick et al. (2013) \\
\hline
\end{tabular}

Table 2. RTMs and ancillary parameters in deriving tropospheric $\mathrm{NO}_{2}$ columns from OMI.

\begin{tabular}{|c|c|c|}
\hline & DOMINO-2 & $\begin{array}{l}\text { Our Reference Retrieval (case } 0 \text { in } \\
\text { Table 4) }\end{array}$ \\
\hline RTM & $\begin{array}{l}\text { DAK v3.0 (polarized, parallel } \\
\text { atmosphere) }\end{array}$ & $\begin{array}{l}\text { LIDORT v3.6 (unpolarized, curved } \\
\text { atmosphere) }\end{array}$ \\
\hline $\begin{array}{l}\text { Calculation for } \\
\text { individual pixels }\end{array}$ & $\begin{array}{l}\text { Interpolated from a look-up } \\
\text { table }\end{array}$ & $\begin{array}{l}\text { Pixel-specific radiative transfer model- } \\
\text { ing, no look-up table }\end{array}$ \\
\hline Surface reflectance & OMLER v1 ( 3 yr average; $\left.0.5^{\circ}\right)$ & BRDF, MCD43C 2 collection $5\left(0.05^{\circ}\right)$ \\
\hline Surface pressure & $\begin{array}{l}\text { TM4 }\left(3^{\circ} \text { long. } \times 2^{\circ} \text { lat. }\right) \text {, ad- } \\
\text { justed by elevation }\end{array}$ & $\begin{array}{l}\text { GEOS-Chem }\left(0.667^{\circ} \text { long. } \times 0.5^{\circ} \text { lat. }\right) \text {, } \\
\text { adjusted by elevation }\end{array}$ \\
\hline Cloud fraction & $\begin{array}{l}\text { OMCLDO2 v1.1.1.3, by look- } \\
\text { up table }\end{array}$ & Derived here; see Table 3 \\
\hline Cloud pressure & $\begin{array}{l}\text { OMCLDO2 v1.1.1.3, by look- } \\
\text { up table }\end{array}$ & Derived here; see Table 3 \\
\hline Aerosol optical effects & $\begin{array}{l}\text { Treated implicitly as "effective" } \\
\text { clouds }\end{array}$ & $\begin{array}{l}\text { GEOS-Chem simulations; AOD is ad- } \\
\text { justed by AERONET, MAX-DOAS, or } \\
\text { MODIS }\end{array}$ \\
\hline $\begin{array}{l}\text { Pressure levels, temper- } \\
\text { ature profile, and } \mathrm{NO}_{2} \\
\text { vertical profile }\end{array}$ & $\begin{array}{l}\text { TM4 }\left(3^{\circ} \text { long. } \times 2^{\circ} \text { lat., } 34\right. \\
\text { layers with } \sim 5 \text { layers below } \\
1.5 \mathrm{~km})^{*}\end{array}$ & $\begin{array}{l}\text { GEOS-Chem }\left(0.667^{\circ} \text { long. } \times 0.5^{\circ}\right. \\
\text { lat., } 47 \text { layers with } \sim 10 \text { layers below } \\
1.5 \mathrm{~km})^{*}\end{array}$ \\
\hline
\end{tabular}

* The pressure levels are recalculated according to the elevation-adjusted surface pressure, while the VMRs of $\mathrm{NO}_{2}$ are not changed in individual layers (Zhou et al., 2009).

the effect of surface reflectance anisotropy. These As values are affected by the presence of aerosols (Herman et al., 2001; Kleipool et al., 2008). For a given ground pixel of OMI, the surface pressure is interpolated to the pixel center from TM4 simulations on a $3^{\circ}$ long. $\times 2^{\circ}$ lat. grid, and subsequently corrected for differences between the corresponding effective ground elevation and the high-resolution elevation obtained from the DEM_3KM database (Boersma et al., 2011). The vertical profile of $\mathrm{NO}_{2}$ is adjusted subsequently by maintaining the volume mixing ratios (VMRs) of $\mathrm{NO}_{2}$ in the individual layers so that the profile shape is not changed. The detailed formulation of the adjustments is presented by Zhou et al. (2009) and Boersma et al. (2011).

DOMINO-2 takes the cloud fraction and cloud pressure information from the OMCLDO2 v1.1.1.3 data set (Acarreta et al., 2004; Sneep et al., 2008). (Hereafter the version number of OMCLDO2 is dropped for simplicity.) Table 3 summarizes the ancillary parameters used for deriving OMCLDO2. Compared to DOMINO-2, OMCLDO2 assumes a time-invariant relationship between pressure and height (i.e., the midlatitude summer profile from Anderson et al., 1986) and uses the pixel-specific ground elevation to determine the respective Ps. The effect of the inconsistent treatments of Ps between DOMINO-2 and OMCLDO2 is analyzed in Sects. 3 and 4.

The retrieval processes of both DOMINO-2 and OMCLDO2 do not explicitly account for the effect of aerosols (scattering, absorption, and vertical profile). The cloud fraction and cloud pressure retrieved from OMCLDO2 are thus considered as "effective" parameters that may include partial information about the presence of aerosols (Boersma et al., 2011). The implicit treatment of aerosols affects the retrieval of $\mathrm{NO}_{2}$ over East China given its high aerosol concentrations.

\subsection{Our reference retrieval}

Using the LIDORT v3.6 RTM (Spurr, 2008), we improved the AMF code by Palmer et al. (2001), Martin et al. (2002, 2003, 2006), and O'Byrne et al. (2010) to AMFv6 that 
Table 3. RTMs and ancillary parameters in deriving cloud properties from OMI.

\begin{tabular}{|c|c|c|}
\hline & OMCLDO2 v1.1.1.3 & $\begin{array}{l}\text { Our Reference Retrieval (case } 0 \text { in Ta- } \\
\text { ble 4) }\end{array}$ \\
\hline RTM & $\begin{array}{l}\text { DAK v3.0 (polarized, parallel } \\
\text { atmosphere) }\end{array}$ & $\begin{array}{l}\text { LIDORT v3.6 (unpolarized, curved } \\
\text { atmosphere) }\end{array}$ \\
\hline $\begin{array}{l}\text { Calculation for } \\
\text { individual pixels }\end{array}$ & $\begin{array}{l}\text { Interpolated from a look-up ta- } \\
\text { ble }\end{array}$ & $\begin{array}{l}\text { Pixel-specific radiative transfer model- } \\
\text { ing, no look-up table }\end{array}$ \\
\hline Surface reflectance & OMLER v1 (3 yr average, $\left.0.5^{\circ}\right)$ & BRDF, MCD43C2 collection $5\left(0.05^{\circ}\right)$ \\
\hline Surface pressure & $\begin{array}{l}\text { Interpolated from a fixed } \\
\text { pressure-height relation (mid- } \\
\text { latitude summer profile) }\end{array}$ & $\begin{array}{l}\text { GEOS-Chem }\left(0.667^{\circ} \text { long. } \times 0.5^{\circ} \text { lat. }\right) \text {, } \\
\text { adjusted by elevation }\end{array}$ \\
\hline Aerosol optics & No aerosols & $\begin{array}{l}\text { GEOS-Chem simulations; AOD is } \\
\text { adjusted by AERONET, MAX-DOAS, } \\
\text { or MODIS }\end{array}$ \\
\hline $\begin{array}{l}\text { Pressure levels and } \\
\text { temperature profile }\end{array}$ & $\begin{array}{l}\text { Fixed dependence on height } \\
\text { (midlatitude summer profile) }\end{array}$ & $\begin{array}{l}\text { GEOS-Chem }\left(0.667^{\circ} \text { long. } \times 0.5^{\circ}\right. \\
\text { lat., } 47 \text { layers with } \sim 10 \text { layers below } \\
1.5 \mathrm{~km})^{*}\end{array}$ \\
\hline
\end{tabular}

* The pressure levels are recalculated according to the elevation-adjusted surface pressure.

simultaneously accounts for the coupled effects of aerosols and clouds on the $\mathrm{NO}_{2}$ retrieval and for the angular distribution of surface reflectance. This code calculates the tropospheric AMFs of $\mathrm{NO}_{2}$ for individual OMI pixels without the use of a LUT. We derived the VCDs of $\mathrm{NO}_{2}$ by dividing the tropospheric SCDs from DOMINO-2 by the newly calculated AMFs. Prior to the retrieval of $\mathrm{NO}_{2}$, we derived the cloud information ( $\mathrm{CF}$ and $\mathrm{CP}$ ) based on the top-ofatmosphere reflectance and the $\mathrm{O}_{2}-\mathrm{O}_{2} \mathrm{SCD}$ data from OMCLDO2 (Acarreta et al., 2004; Sneep et al., 2008) using ancillary parameters that are consistent with the $\mathrm{NO}_{2}$ retrieval. Tables 2 and 3 summarize the ancillary parameters used in our retrieval processes for $\mathrm{NO}_{2}$ and clouds, respectively. The retrieval here is referred to as our "reference retrieval" (case 0 in Table 4) in order to be distinguished from the sensitivity tests throughout the text (cases 1-17).

For surface reflectance, our reference retrieval accounts for the effect of surface bidirectional reflectance distribution function (BRDF) (Zhou et al., 2010). We adopted the MCD43C2 data set (Lucht et al., 2000) from the Moderate Resolution Imaging Spectroradiometer (MODIS) that provides the coefficients for three kernels (isotropic, volumetric, and geometric) determining the BRDF at $440 \mathrm{~nm}$. MCD43C2 provides 16-day average coefficients for every 8 days of a year on a $0.05^{\circ}$ long. $\times 0.05^{\circ}$ lat. grid (the first file contains the average values over 1-16 January, and the second file represents 9-24 January, etc.). To fill the missing values, we interpolated the data temporally using the adjacent two data sets, spatially with the surrounding $5 \times 5$ grid cells, temporally using the respective data sets in the adjacent two years, and then temporally using the 2005-2011 average values representing the same days. The interpolation was done in the above order, and was exited once the missing value had been filled. We then conducted spatial smoothing $(5 \times 5$ grid cells $)$ on the coefficients to remove the influence of ice or snow that may not have been fully eliminated in MCD43C2. As a final step, we derived the kernel coefficients for an OMI pixel in a given day from the high-resolution data set by spatial mapping and temporal interpolation.

Our reference retrieval obtains surface pressure and $\mathrm{NO}_{2}$ profiles from the nested GEOS-Chem model $\left(0.667^{\circ}\right.$ long. $\times$ $0.5^{\circ}$ lat.) with further adjustments in accordance to the pixelspecific surface elevation as done for DOMINO-2. (See Appendix A for a brief model description.) The nested GEOSChem $\mathrm{NO}_{2}$ profiles are also used for Europe (Vinken et al., 2013). For surface elevation, we adopted the GMTED2010 data set at $30 \mathrm{arcsec}$ (http://topotools.cr.usgs.gov/GMTED_ viewer/). GEOS-Chem simulates vertical mixing in the planetary boundary layer (PBL) fairly well (Lin and McElroy, 2010). Compared to TM4, the nested GEOS-Chem has a much higher resolution, thus improving the representation of topography, emissions, and the nonlinear chemistry. We obtained the model outputs at the local time of OMI pixels.

Our reference retrieval explicitly accounts for the effect of aerosol optics by including in the RTM calculation the vertical profiles of aerosol extinction coefficient (EC), singlescattering albedo (SSA), and phase functions. We adopted the temporally and spatially varying aerosol information (EA, SSA, phase functions, and vertical profiles for individual aerosol types) at the local time of OMI pixels from the nested GEOS-Chem simulation (Lin, 2012). (See Appendix A for descriptions of the aerosol simulation.) GEOS-Chem captures the spatial distribution of AOD at $550 \mathrm{~nm}$ over East China in 2006 observed from MODIS, with a positive bias in 
Table 4. Retrieving VCDs of $\mathrm{NO}_{2}$ from OMI by altering the ancillary parameters*

\begin{tabular}{|c|c|c|c|c|c|}
\hline Case & $\begin{array}{l}\text { Tested } \\
\text { parameter }\end{array}$ & $\begin{array}{l}\text { Differences from our reference retrieval } \\
\text { (case } 0)\end{array}$ & NMB & RMA slope & $R^{2}$ \\
\hline 0 & & Reference retrieval & $-46 \%$ & 0.51 & 0.96 \\
\hline 1 & & $\begin{array}{l}\text { Mimicking DOMINO-2, but not using } \\
\text { the LUT }\end{array}$ & $-9 \%(-5 \%)$ & $1.06(1.11)$ & $0.85(0.72)$ \\
\hline 2 & & $\begin{array}{l}\text { Mimicking DOMINO-2, but adopting } \\
\text { surface pressure from OMCLDO2 and } \\
\text { not using the LUT }\end{array}$ & $-27 \%$ & 0.83 & 0.71 \\
\hline 3 & $\begin{array}{l}\text { Surface } \\
\text { reflectance }\end{array}$ & $\begin{array}{l}\text { Using blue-sky surface albedo derived } \\
\text { from MODIS BRDF }\end{array}$ & $-47 \%$ & 0.51 & 0.96 \\
\hline 4 & $\begin{array}{l}\text { Surface } \\
\text { reflectance }\end{array}$ & $\begin{array}{l}\text { Using black-sky surface albedo derived } \\
\text { from MODIS BRDF }\end{array}$ & $-47 \%$ & 0.51 & 0.96 \\
\hline 5 & $\begin{array}{l}\text { Surface } \\
\text { reflectance }\end{array}$ & $\begin{array}{l}\text { Using } 5 \mathrm{yr} \text { average surface albedo from } \\
\text { OMI (OMLER v3) }\end{array}$ & $-51 \%$ & 0.47 & 0.96 \\
\hline 6 & $\begin{array}{l}\text { Surface } \\
\text { reflectance }\end{array}$ & $\begin{array}{l}\text { Using } 3 \text { yr average surface albedo from } \\
\text { OMI (OMELR v1), as in DOMINO-2 }\end{array}$ & $-46 \%$ & 0.53 & 0.93 \\
\hline 7 & $\mathrm{NO}_{2}$ profile & $\begin{array}{l}\text { Adopting vertical profiles of } \mathrm{NO}_{2} \\
\text { VMRs from MAX-DOAS }\end{array}$ & $-36 \%$ & 0.65 & 0.96 \\
\hline 8 & $\mathrm{NO}_{2}$ profile & $\begin{array}{l}\text { Adopting vertical profiles of } \mathrm{NO}_{2} \\
\text { VMRs from TM4, as in DONIMO-2 }\end{array}$ & $-39 \%$ & 0.63 & 0.95 \\
\hline 9 & $\mathrm{NO}_{2}$ profile & $\begin{array}{l}\text { Assuming an exponential decrease of } \\
\mathrm{NO}_{2} \mathrm{VMRs} \text { from surface to } 1.5 \mathrm{~km} \text { with } \\
\text { a scale height of } 0.25 \mathrm{~km}\end{array}$ & $-24 \%$ & 0.83 & 0.94 \\
\hline 10 & $\mathrm{NO}_{2}$ profile & $\begin{array}{l}\text { Assuming a constant VMR of } \mathrm{NO}_{2} \\
\text { from surface to } 1.5 \mathrm{~km}\end{array}$ & $-52 \%$ & 0.45 & 0.96 \\
\hline 11 & $\mathrm{NO}_{2}$ profile & $\begin{array}{l}\text { Assuming an exponential decrease of } \\
\mathrm{NO}_{2} \mathrm{VMRs} \text { from surface to } 3.0 \mathrm{~km} \text { with } \\
\text { a scale height of } 0.25 \mathrm{~km}\end{array}$ & $2 \%$ & 1.28 & 0.93 \\
\hline 12 & AOD & Assuming no AOD & $-39 \%$ & 0.67 & 0.90 \\
\hline 13 & $\begin{array}{l}\text { Aerosol } \\
\text { absorption }\end{array}$ & Assuming no aerosol absorption & $-54 \%$ & 0.41 & 0.94 \\
\hline 14 & $\begin{array}{l}\text { Aerosol } \\
\text { absorption }\end{array}$ & Doubling aerosol absorption & $-39 \%$ & 0.64 & 0.92 \\
\hline 15 & Aerosol profile & $\begin{array}{l}\text { Assuming constant aerosol extinction } \\
\text { coefficient in the troposphere }\end{array}$ & $-32 \%$ & 0.72 & 0.87 \\
\hline 16 & Aerosol profile & $\begin{array}{l}\text { Putting all tropospheric aerosols at the } \\
\text { PBL top }\end{array}$ & $-39 \%$ & 0.57 & 0.76 \\
\hline 17 & Aerosol profile & $\begin{array}{l}\text { Putting all tropospheric aerosols at the } \\
\text { tropopause }\end{array}$ & $-29 \%$ & 0.77 & 0.69 \\
\hline
\end{tabular}

* The NMB, slope, and $R^{2}$ are relative to MAX-DOAS $\mathrm{NO}_{2}$ for the 30 daily data pairs. Results in parentheses are for DOMINO-2 relative to MAX-DOAS. 
winter and a negative bias in summer on average (Lin et al., 2012).

Prior to our RTM calculation, we further constrained the model AOD using measurements from the AErosol RObotic NETwork (AERONET), MODIS, and MAX-DOAS. We scaled the simulated concentrations of all aerosol types simultaneously based on the ratio of observed to modeled AOD, and thus adjusted modeled AOD, SSA, and phase functions together. The same wavelength was ensured in comparing each pair of model and observation. For the Tai' An site, we used the AOD data at $476 \mathrm{~nm}$ retrieved from the MAX-DOAS measurements (Irie et al., 2011). For IAP and Xianghe (Liu et al., 2007), we used the AERONET data at $550 \mathrm{~nm}$ at the hour of the MAX-DOAS measurements. For seven days (34 pixels) without AERONET data, we used the MODIS AOD data at $550 \mathrm{~nm}$ from the MYD04 collection 5/5.1 level-2 product (Remer et al., 2008). For a given day, the MYD04 data were averaged over all valid values within $0.25^{\circ}$ of the respective MAX-DOAS sites. The MODIS AOD are affected by cloud contamination and errors in surface reflectance (Wang et al., 2010; Hyer et al., 2011). The consequent effects on our cloud and $\mathrm{NO}_{2}$ retrievals are small compared to the effects of potential errors in modeled SSA and vertical distribution of aerosols. After the aerosol adjustments, the resulting AOD, when converted to $550 \mathrm{~nm}$, ranges from 0.07 to 2.23 , with a mean value of 0.61 for the 127 OMI pixels complying with our spatial constraints detailed in Sect. 2.4.1. At $550 \mathrm{~nm}$, the adjusted AOD is highly correlated to the GEOS-Chem simulated AOD $\left(R^{2}=0.79\right)$ with an increase by 0.06 on average. The SSA at $550 \mathrm{~nm}$ is 0.934 on average $(\min =0.870, \max =0.986)$, reflecting the high concentrations of black carbon in East China (Yang et al., 2011).

We converted the aerosol optics at $550 \mathrm{~nm}$ outputted from GEOS-Chem to other wavelengths $(477 \mathrm{~nm}$ for comparison with AOD measurements at Tai' An, $475 \mathrm{~nm}$ for $\mathrm{O}_{2}-\mathrm{O}_{2}$ cloud retrieval, and $438 \mathrm{~nm}$ for $\mathrm{NO}_{2}$ retrieval). The conversion was based on the size distributions, refractive indices, and hygroscopic growth rates of individual aerosol types prescribed in GEOS-Chem (i.e., in the same manner as done in GEOSChem). For this purpose we also adopted the modeled relative humidity.

The GEOS-Chem aerosol vertical profile generally reproduces that observed by the Cloud-Aerosol Lidar with Orthogonal Polarization (CALIOP) over East Asia, with a tendency for GEOS-Chem to underestimate the abundance of aerosols in the free troposphere (Ford and Heald, 2012; van Donkelaar et al., 2013). We thus test the effects of aerosol vertical profiles on the retrievals of clouds and $\mathrm{NO}_{2}$ in Sect. 5.3.2.

\subsection{Criteria for selecting OMI and MAX-DOAS data}

\subsubsection{Spatial constraint and consistency between OMI and MAX-DOAS measurements}

As the MAX-DOAS sites are located in the urban or suburban areas, the spatial variability of $\mathrm{NO}_{2}$ needs to be considered in selecting suitable OMI and MAX-DOAS data for comparison. Parameters that can be used to adjust the spatial consistency between the space- and ground-based measurements include the viewing zenith angle (VZA) of OMI and the distance from the OMI pixel center to the respective MAX-DOAS site (hereafter referred to as pixel-center distance). For our analysis, the distance is restricted to be shorter than $25 \mathrm{~km}$ and the VZA smaller than $30^{\circ}$, unless stated otherwise. A stricter spatial constraint would significantly reduce the number of days with suitable data, not allowing for a meaningful analysis. The dependence on distance and VZA of the comparison between OMI and MAX-DOAS data is discussed in Appendix B.

Note that the spatial constraints here cannot fully eliminate the spatial inconsistency between MAX-DOAS and OMI measurements, due to the inevitable spatial inconsistency between the ground- and space-based remote sensing. In particular, the MAX-DOAS sensors always face north and typically sample a horizontal distance of a few kilometers, while an OMI pixel represents an area of $13 \times 24 \mathrm{~km}^{2}$ or larger. Brinksma et al. (2008) showed that changing the azimuth angle of the MAX-DOAS sensor can result in differences by a factor of $10-350 \%$ (by $50 \%$ on average) in the retrieved $\mathrm{NO}_{2}$ in Cabauw, the Netherlands, due to the influences of local sources and/or sinks (see their Fig. 6). Irie et al. (2012) also showed that the vicinity of the polluted Yokosuka site undergoes larger horizontal variability of $\mathrm{NO}_{2}$. For Chinese sites, the influence of horizontal inhomogeneity in $\mathrm{NO}_{2}$ was suggested to be about $10-30 \%$ for MAX-DOAS measurements taken at the Chinese Meteorological Administration in polluted urban Beijing (Ma et al., 2013) and about 10$15 \%$ for less polluted Tai'An, Mangshan, and Rudong (Irie et al., 2012) (see Fig. 1 for locations and $\mathrm{NO}_{2}$ pollution gradient at these sites). The effect of horizontal inhomogeneity is also in line with the pixel-specific comparison in Fig. 4a-c that show notable scattering in the OMI data in a given day corresponding to a MAX-DOAS site.

We tentatively estimate the overall effect of horizontal inhomogeneity (and spatial inconsistency between space- and ground-based measurements) to be $20-30 \%$ for the OMI pixels analyzed here, considering that about $77 \%$ of these OMI pixels are located near the polluted Beijing IAP with larger $\mathrm{NO}_{2}$ gradient. This estimate is preliminary since previous studies suggested the spatial inhomogeneity to be strongly location-, time-, and meteorology-dependent (Brinksma et al., 2008; Irie et al., 2012; Ma et al., 2013). 


\subsubsection{Temporal constraint}

Temporally, MAX-DOAS measures $\mathrm{NO}_{2}$ much more frequently than OMI throughout the course of a day. In many days, it observes rapid changes in $\mathrm{NO}_{2}$ within a short time period. To reduce the effect of the temporal variation of $\mathrm{NO}_{2}$ in comparing the ground- and space-based measurements, here the measurement from an OMI pixel is considered to have a temporally consistent counterpart from MAX-DOAS only if (1) there exist two or more MAX-DOAS data within $1.5 \mathrm{~h}$ of the time of the OMI pixel and (2) the standard deviation of these MAX-DOAS data does not exceed $20 \%$ of their mean value. In this case, the mean value of the MAX-DOAS data points is paired with the OMI value for comparison.

\subsubsection{Other constraints}

We excluded the OMI pixels affected by row anomaly, icy/snowy ground, or high cloud coverage. DOMINO-2 restricts valid $\mathrm{NO}_{2}$ data to the pixels with cloud radiance fractions (CRFs) below 0.5 . It also implicitly excludes the pixels with high aerosol loadings, since its cloud information is influenced by the presence of aerosols. This may not be desirable for aerosol-polluted regions such as East China, particularly when the effects of aerosols can otherwise be characterized. By comparison, our reference retrieval explicitly accounts for the effect of aerosol optics, thus providing information that is more specific to clouds. For example, there is a heavy aerosol loading near the IAP site on 28 December 2008 with the AERONET AOD close to 2. For this day, our reference retrieval suggests low cloud coverage in an OMI pixel with a CRF of $6 \%$, in contrast to the CRF at $55 \%$ suggested by DOMINO-2. Detailed comparison of the cloud information is presented in Sect. 3. Therefore, we used the CRF values derived from our reference retrieval to determine the OMI pixels with low cloud coverage $(\mathrm{CRF} \leq 0.5)$ in comparing OMI to MAX-DOAS data. Had the CRFs from DOMINO-2 been used for constraint, the number of pixels would have decreased by $25 \%$.

\subsubsection{Available data complying with all constraints}

The constraints for spatial and temporal consistency, row anomaly, ground conditions, and cloud interference together result in 127 pixels of OMI over 30 days with suitable OMI and MAX-DOAS data. A total of 98 pixels (in 23 days) correspond to the IAP site, 27 pixels (in 6 days) correspond to the Tai' An site, and 2 pixels (in 1 day) correspond to the Xianghe site. The number of pixels (days) is 37 (10) in winter, 12 (4) in spring, 30 (7) in summer, and 48 (9) in fall, with relatively good seasonal representativeness.

\section{Evaluating ancillary parameters for deriving DOMINO-2 and our reference retrieval}

Unlike DOMINO-2, our reference retrieval accounts for surface BRDF. Here we used the respective bidirectional reflectance factor (BRF) to illustratively compare with the OMI albedo (OMLER v1) adopted by DOMINO-2. We neglected the scale factor $\pi$ when deriving the BRF from the BRDF (Lucht et al., 2000). Figure 2a shows that the BRF is in the same range as the OMI albedo (0.03-0.08), while it is smaller than the OMI albedo by 0.023 averaged over the pixels. The two data correlate poorly with the coefficient of determination $\left(R^{2}\right)$ below 0.05 . Also, the MODIS BRF varies from one pixel to another more significantly than the OMI albedo (note the apparent horizontal lines in Fig. 2a). The lack of correlation highlights the spatial and angular dependence of surface reflectance not fully accounted for in the OMI albedo data.

The Ps adjustment in deriving DOMINO-2 leads to unrealistically high Ps for most of the 127 pixels analyzed here, an apparent result of the likely overestimate in the TM4 Ps data. The adjusted Ps is larger than $1050 \mathrm{hPa}(1100 \mathrm{hPa})$ in $76 \%(24 \%)$ of the pixels (Fig. 2b). It also exceeds the Ps assumed in OMCLDO2 by $57.7 \mathrm{hPa}$ on average. For the 100 pixels near the IAP or Xianghe sites, the adjusted Ps overestimates the Ps observed at the Nanjiao $\left(116.47^{\circ} \mathrm{E}, 39.80^{\circ} \mathrm{N}\right.$; $31 \mathrm{~m}$ ) ground meteorological station in the southeast of urban Beijing (mean bias $=75.2 \mathrm{hPa}, R^{2}=0.35$ ). Further analysis shows positive biases in the DOMINO-2 Ps data over various regions of East China with no clear dependence on land use types (Lin et al., 2014). By comparison, the Ps derived in our reference retrieval is consistent with the observed Ps at Nanjiao (mean bias $=-9.1 \mathrm{hPa}, R^{2}=0.65$ ).

Figure 2c-e compare the $\mathrm{CF}, \mathrm{CP}$, and CRF between DOMINO-2 and our reference retrieval. As mentioned in Sect. 2.2, the DOMINO-2 CF and CP are taken from OMCLDO2. The CFs and CRFs for DOMINO-2 are larger than those derived from our reference retrieval for most pixels ( 0.100 versus 0.063 for $\mathrm{CF}$ on average and 0.326 versus 0.180 for CRF), as explained by the different treatments concerning aerosols. On the other hand, our reference retrieval suggests higher CP than DOMINO-2 (OMCLDO2) with a mean difference by about $30 \mathrm{hPa}$.

For the assumed vertical profile of $\mathrm{NO}_{2}$, our reference retrieval differs from DOMINO-2 due to the differences between the coarse-resolution TM4 and high-resolution GEOSChem simulations as well as the different adjustments in accordance to the Ps. Figure $3 \mathrm{~b}$ presents an illustrative example of the vertical profiles assumed by DOMINO-2 and by our reference retrieval for a pixel on 28 December 2008. Compared to our reference retrieval, the $\mathrm{NO}_{2}$ profile in DOMINO-2 for this pixel is associated with much higher Ps and also assumes $\mathrm{NO}_{2}$ to be more concentrated near the ground. The differences contribute partly to the much lower AMF in DOMINO-2 than our reference retrieval ( 0.32 versus $0.90)$. 

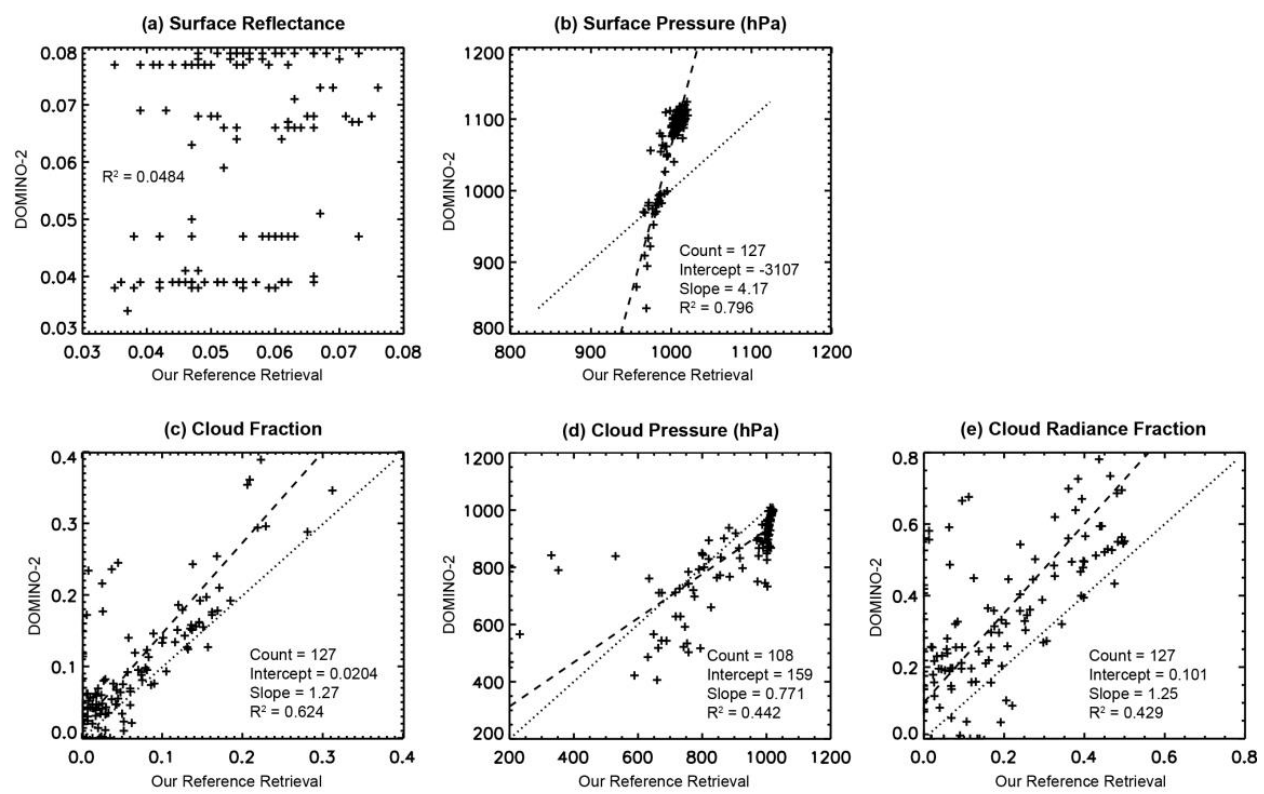

Fig. 2. Scatter plots between DOMINO-2 ( $y$ axis) and our reference retrieval ( $x$ axis) for surface reflectance, surface pressure, cloud fraction, cloud pressure, and cloud radiance fraction across the individual pixels. For (a), the OMLER v1 albedo data ( $y$ axis) are compared to the MODIS bidirectional reflectance factors (BRF, $x$ axis). The criteria for pixel selection are presented in Sect. 2.4. The number of pixels is smaller for cloud pressure because cloud fraction is 0 in some pixels. Also shown are the statistics from the RMA regression; the dashed line indicates the regression curve and the dotted line denotes the $1: 1$ relationship.

\section{Evaluating DOMINO-2 and our reference retrieval using MAX-DOAS measurements}

The scatter plots in Fig. $4 \mathrm{a}$ and $\mathrm{b}$ compare the $\mathrm{NO}_{2}$ columns derived for the 127 OMI pixels with their MAX-DOAS counterparts. There is significant scattering in the DOMINO2 data when the MAX-DOAS values are large $(>60 \times$ $10^{15} \mathrm{molec}^{-2}$, Fig. 4a). The scattering is due largely to errors in the assumed ancillary parameters, and is much reduced by our reference retrieval (Fig. $4 \mathrm{~b}$ ). The remaining scattering is due likely to the actual $\mathrm{NO}_{2}$ variability in the vicinity of the MAX-DOAS site.

The scatter plots in Fig. 4d and e compare the daily $\mathrm{NO}_{2}$ data derived from OMI to MAX-DOAS measurements. Here each OMI value represents the average over all pixels in a day. Our reference retrieval captures the day-to-day variability of MAX-DOAS NO $2\left(R^{2}=0.96\right)$. However, the retrieved $\mathrm{NO}_{2}$ columns are about half of MAX-DOAS, with a normalized mean bias (NMB) at $-46 \%$ and a reduced major axis (RMA) slope at 0.51 . The magnitude of $\mathrm{NO}_{2}$ columns in DOMINO-2 is closer to MAX-DOAS (NMB $=-5 \%$ ) with a reduced correlation $\left(R^{2}=0.72\right)$. Note that the correlation for DOMINO-2 here is comparable to the findings from previous studies (e.g., Irie et al., 2012).

To further evaluate the consistency between MAX-DOAS and $\mathrm{OMI} \mathrm{NO}_{2}$ data, we mimicked the retrieval process of DOMINO-2 by adopting its ancillary parameters including As, Ps, CF, CP, pressure levels, and vertical profiles of tem- perature and $\mathrm{NO}_{2}$ (case 1 in Table 4). However, we performed pixel-specific LIDORT radiative transfer modeling to calculate the layer AMFs instead of using the LUT produced with the DAK RTM (see Appendix C for detailed analyses). The mimicked retrieval process largely reproduces the $\mathrm{NO}_{2}$ columns in DOMINO-2 (Fig. 4c, f), with a negative mean difference of $4 \%$ for the 30 daily data. It better captures the day-to-day variability of MAX-DOAS $\left(R^{2}\right.$ increases from 0.72 to 0.85 for the 30 daily data pairs), due to the remaining differences in the retrieval process detailed in Appendix C.

We then analyzed the effects of the overestimated Ps in DOMINO-2. As detailed in Sect. 3, DOMINO-2 overestimates the observed Ps by $75.2 \mathrm{hPa}$ on average and adjusts the pressure dependence of $\mathrm{NO}_{2}$ accordingly. It adopts the CP from OMCLDO2 (that assumes lower Ps) without additional adjustments. Thus it puts more $\mathrm{NO}_{2}$ below the cloud top, consequently lowering the AMF. In addition, DOMINO2 adopts the OMCLDO2 CF data that are overestimated due to the influence of aerosols. This further enhances the sensitivity to the treatments of Ps and CP. As a result of changing the retrieval process of case 1 by adopting the Ps from OMCLDO2 (case 2 in Table 4), the resulting $\mathrm{NO}_{2}$ columns are lower than MAX-DOAS by $27 \%$ on average. Therefore, that the mean DOMINO-2 $\mathrm{NO}_{2}$ column is close to the MAXDOAS value is contributed in part by the overestimate in Ps. 

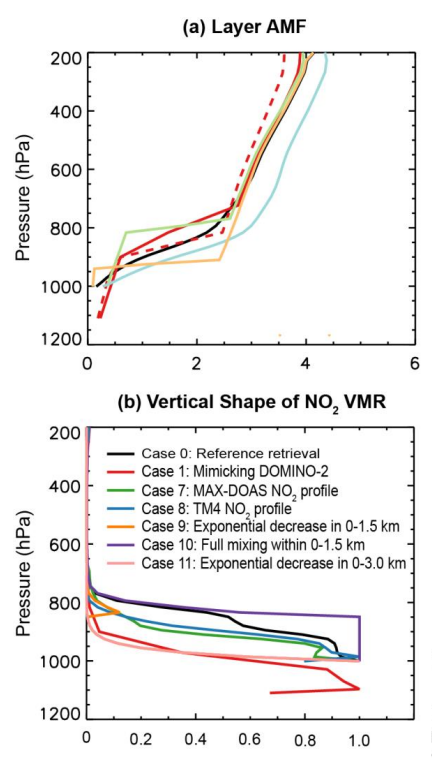

(c) Aerosol Extinction Coefficient and SSA

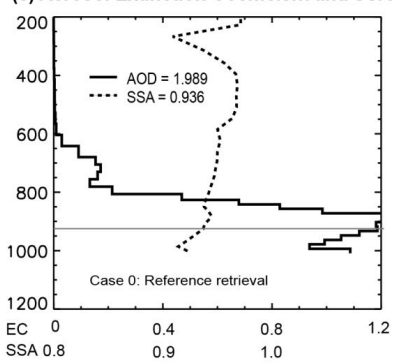

Fig. 3. (a) The pressure dependence of layer AMFs for an OMI pixel on 28 December 2008. The derived cloud radiance fraction (CRF) and AMF are depicted as well, together with the AMF from DOMINO-2 (with respect to the red dashed line). (b) The vertical shape of $\mathrm{NO}_{2}$ (i.e., VMRs of $\mathrm{NO}_{2}$ normalized to the maximum VMR). (c) The vertical distributions of aerosol extinction coefficient $\left(\mathrm{EC}, \mathrm{km}^{-1}\right)$ and SSA assumed in our reference retrieval (case $0)$. The thickness of the individual layers is shown in the EC line. The horizontal grey line depicts the PBL top.

\section{Effects of ancillary assumptions in retrieving $\mathrm{NO}_{2}$ columns from $\mathrm{OMI}$}

Section 4 shows that our reference retrieval is highly correlated to MAX-DOAS with a significant underestimate in magnitude. This section explores the extent to which our retrieval is affected by ancillary assumptions.

Sections 5.1-5.3 evaluate the impacts of individual ancillary parameters on the retrievals of clouds and $\mathrm{NO}_{2}$, including surface reflectance, vertical profile of $\mathrm{NO}_{2}$, and aerosol characteristics. The sections start with conceptual analyses of individual parameters, followed by various sensitivity tests perturbing the parameters upon our reference retrievals of clouds and $\mathrm{NO}_{2}$ (cases 3-17 in Table 4, with statistics for NMB, RMA slope, and $R^{2}$ ). Section 5.4 summarizes the sensitivity tests, identifying the relative contributions of individual factors affecting the comparisons between OMI and MAX-DOAS $\mathrm{NO}_{2}$.

\subsection{Effects of surface reflectance}

Figure 5 shows that, in retrieving the cloud information, an increase in Rs will enhance the AMF of $\mathrm{O}_{2}-\mathrm{O}_{2}$ that is compensated by a decrease in CP. The increased Rs also enhances the reflectance at top of atmosphere $\left(R_{\mathrm{TOA}}\right)$ with a consequent reduction in the retrieved CF. The reduction in CF will further reduce the retrieved $\mathrm{CP}$ if the amount of $\mathrm{AMF}$ in the cloudy portion of the pixel $\left(\mathrm{AMF}_{\mathrm{cl}}\right)$ is smaller than the $\mathrm{AMF}$ in the clear-sky portion $\left(\mathrm{AMF}_{\mathrm{cr}}\right)$, whereas it has an opposite effect when the $\mathrm{AMF}_{\mathrm{cl}}$ exceeds the $\mathrm{AMF}_{\mathrm{cr}}$. In retrieving $\mathrm{NO}_{2}$, the increased Rs also enhances the AMF of $\mathrm{NO}_{2}$.

Table 4 describes various sensitivity retrievals with perturbed surface reflectance. Cases 3 and 4 assume blue-sky albedo and black-sky albedo, respectively, derived from the MODIS BRDF data. The black-sky albedo accounts for the incident solar radiation reflected by isotropic surface, while the blue-sky albedo accounts for both direct and diffuse radiation reaching the ground. The relative contributions of direct and diffuse radiation are determined using the LUT developed by Lucht et al. (2000). The resulting blue-sky albedo and black-sky albedo differ insignificantly from the MODIS BRF, with a difference within \pm 0.01 for all pixels. They thus result in cloud properties and $\mathrm{NO}_{2}$ columns very close to our reference retrieval (Table 4).

Case 5 adopts the monthly climatological surface albedo data set based on the OMI measurements over 2005-2009 (OMLER v3, $0.5^{\circ}$ long. $\times 0.5^{\circ}$ lat.). During our retrieval process, the albedo for a given day is interpolated from the closest two months. The resulting albedo is larger than the MODIS BRF for $78 \%$ of the pixels with a positive mean difference of 0.023. On average, it leads to a lower CF (CRF) by $0.01(0.04)$ than the reference retrieval. The consequently retrieved $\mathrm{NO}_{2}$ columns deviate further from the MAX-DOAS data $(\mathrm{NMB}=-51 \%$ versus $-46 \%$ for the reference retrieval). Pixel by pixel, changes in $\mathrm{NO}_{2}$ columns due to the Rs changes can reach $45 \%$.

Case 6 uses the same albedo as DOMINO-2 (OMLER v1). The resulting changes in $\mathrm{CF}$ are within \pm 0.05 for all pixels (within \pm 0.1 for $C R F$ ). On average, adopting the albedo from DOMINO-2 has a small impact on the AMF and VCD of $\mathrm{NO}_{2}$ due to the changes in clouds compensating for the effects of the perturbed Rs. Nonetheless, the consistency between the retrieved $\mathrm{NO}_{2}$ and MAX-DOAS is reduced slightly ( $R^{2}$ decreases from 0.96 to 0.93 for the 30 daily data pairs). Had the CF and CP not been modified in accordance to the perturbed Rs, the influence of Rs would have been larger.

Overall, various sets of surface reflectance data lead to $\mathrm{NO}_{2}$ columns within $10 \%$ on average for the OMI pixels investigated here. The effects of different surface reflectance data sets are smaller than found for entire Europe (within $20 \%$; Zhou et al., 2010).

\subsection{Effects of the vertical profile of $\mathrm{NO}_{2}$}

The assumed vertical profile of $\mathrm{NO}_{2}$ affects the $\mathrm{NO}_{2}$ retrieval because the layer AMFs decline with height in the troposphere (e.g., Fig. 3a). For example, assuming $\mathrm{NO}_{2}$ to be closer to the ground reduces the AMF with a positive effect on the retrieved $\mathrm{NO}_{2}$ column. The cloud retrieval is not affected. Cases 7-11 perturb the vertical profile of $\mathrm{NO}_{2}$. The 


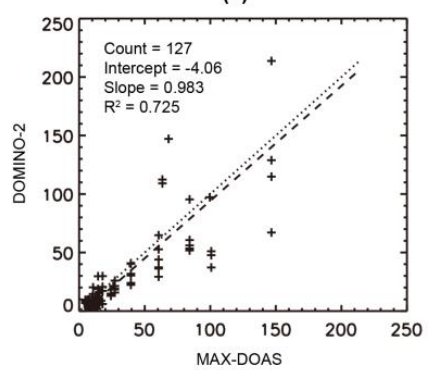

(d)

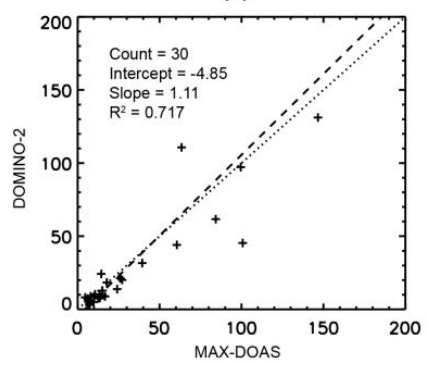

(b)

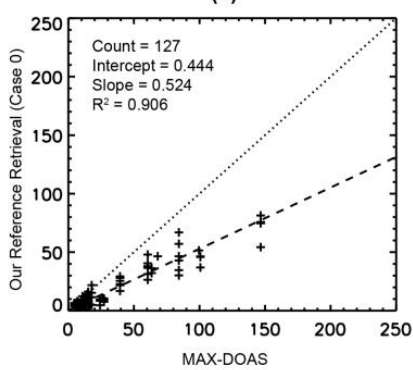

(e)

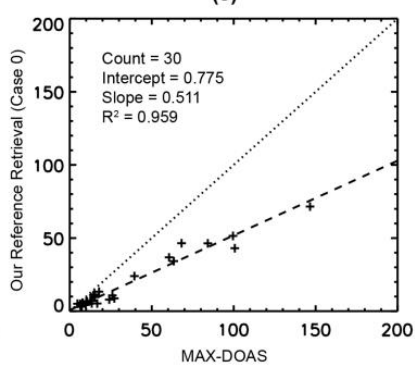

(c)

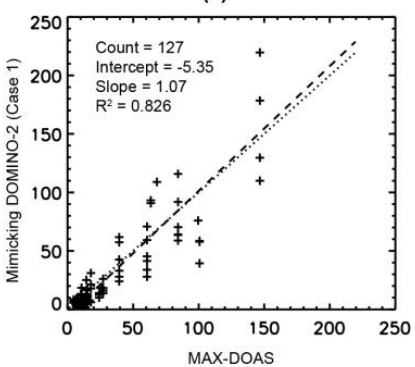

(f)

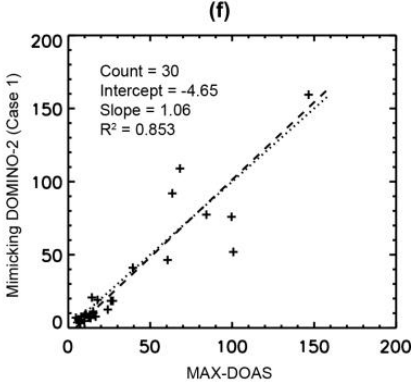

Fig. 4. Scatter plots for $\mathrm{NO}_{2}$ columns $\left(10^{15}\right.$ molec $\left.\mathrm{cm}^{-2}\right)$ from MAX-DOAS measurements and OMI retrievals. Each "+" corresponds to an OMI pixel in $(\mathbf{a}-\mathbf{c})$, as well as to the mean value from all OMI pixels in a day in $(\mathbf{d}-\mathbf{f})$. The criteria for pixel selection are presented in Sect. 2.4. Also shown are the statistics from the RMA regression; the dashed line indicates the regression curve and the dotted line denotes the $1: 1$ relationship. The RMA regression in (a-c) should be interpreted with caution since there may be multiple OMI pixels/data in a day corresponding to a single MAX-DOAS value.
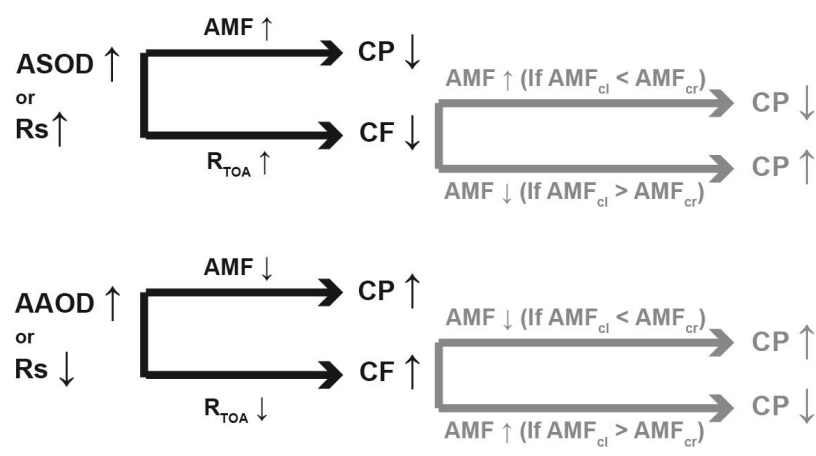

Fig. 5. Effects of surface reflectance (Rs), aerosol scattering optical depth (ASOD), and aerosol absorption optical depth (AAOD) on the retrieval of cloud fraction $(\mathrm{CF})$ and cloud pressure $(\mathrm{CP})$. Aerosols are assumed to be concentrated in the lower troposphere, as for the OMI pixels examined in this study. Grey denotes a secondary effect of the changed $\mathrm{CF}$ on the $\mathrm{CP}$; the effect depends on the amount of $\mathrm{O}_{2}-\mathrm{O}_{2}$ AMF in the cloudy portion of the pixel $\left(\mathrm{AMF}_{\mathrm{cl}}\right)$ relative to the AMF in the clear-sky portion $\left(\mathrm{AMF}_{\mathrm{cr}}\right)$. The changes in $\mathrm{CP}$ have a relatively small effect on the $\mathrm{CF}$ (not depicted here).

resulting profiles are illustrated in Fig. $3 \mathrm{~b}$ for a pixel on 28 December 2008.

As described in Table 4, case 7 adopts the vertical profiles derived from the MAX-DOAS retrieval. Compared to the reference retrieval, it reduces the AMFs of $\mathrm{NO}_{2}$ for $85 \%$ of the pixels, consequently enhancing the retrieved $\mathrm{NO}_{2}$ columns. This is because the MAX-DOAS profile assumes a larger fraction of $\mathrm{NO}_{2}$ near the ground than the fraction simulated by GEOS-Chem (see the illustration in Fig. 3b). The resulting $\mathrm{NO}_{2}$ columns are closer in magnitude to MAX-DOAS $(\mathrm{NMB}=-36 \%)$. Similarly, case 8 adopts the vertical profiles simulated by TM4 (as in DOMINO-2); this leads to a $13 \%$ increase in retrieved $\mathrm{NO}_{2}$ column on average, because TM4 assumes $\mathrm{NO}_{2}$ to be more concentrated near the surface.

Cases 9-11 further test extreme situations for the vertical shape of $\mathrm{NO}_{2}$, aiming to analyze the range of influences of vertical profile on the $\mathrm{NO}_{2}$ retrieval. Case 9 assumes the mixing ratio of $\mathrm{NO}_{2}$ to decline exponentially with height from the surface to $1.5 \mathrm{~km}$ (with a scale height of $0.25 \mathrm{~km}$ and with the column density conserved). Such a gradient is probably overestimated, based on a recent study for urban Paris (i.e., with strong surface emissions) by Dieudonné et al. (2013) showing the $\mathrm{NO}_{2}$ concentration at $300 \mathrm{~m}$ height to be about $50-60 \%$ of the concentration near the surface at the overpass time of OMI. By concentrating $\mathrm{NO}_{2}$ near the ground, case 9 enhances the retrieved $\mathrm{NO}_{2}$ columns with smaller differences from MAX-DOAS (NMB $=-24 \%$ ). Case 11 further increases the retrieved $\mathrm{NO}_{2}$ by assuming an unrealistic exponential decrease of $\mathrm{NO}_{2}$ from surface to $3 \mathrm{~km}$. In contrast, case 10 assumes $\mathrm{NO}_{2}$ to be fully mixed within 0 $1.5 \mathrm{~km}$ above the ground, thus lowering the retrieved $\mathrm{NO}_{2}$ columns $(\mathrm{NMB}=-52 \%)$; this case represents the lower end 
(a) Effects of Neglecting Aerosol Extinction: Contrasting Case 12 to Case 0
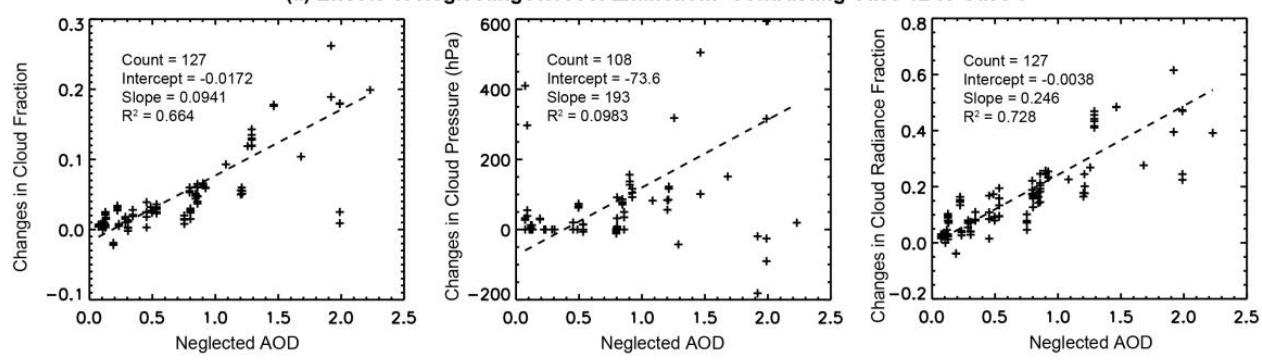

(b) Effects of Neglecting Aerosol Scattering: Contrasting Case 12 to Case 13
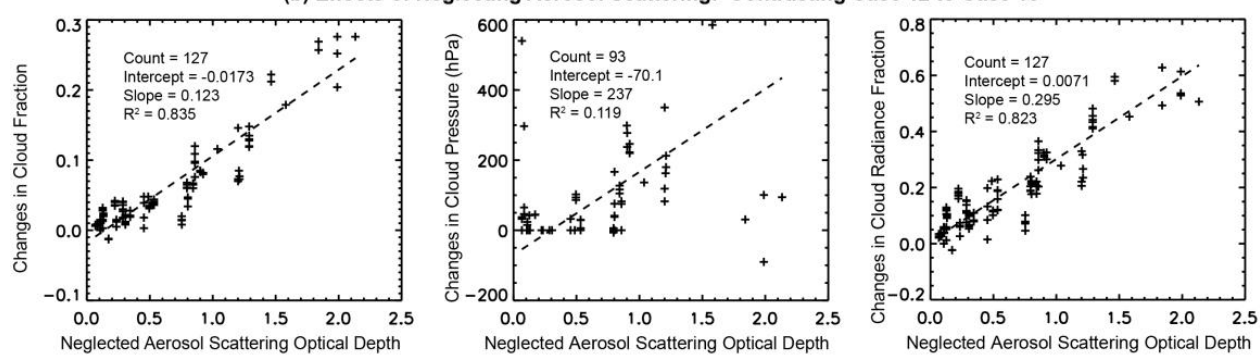

(c) Effects of Neglecting Aerosol Absorption: Contrasting Case 13 to Case 0
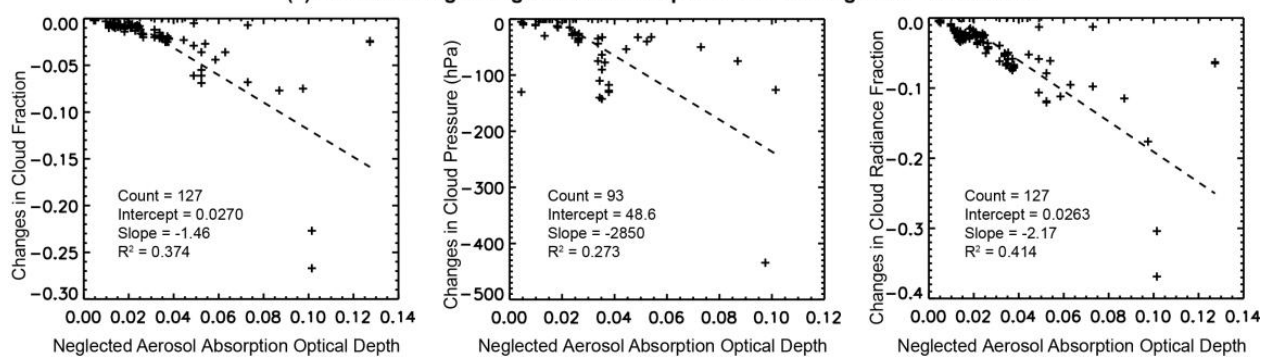

Fig. 6. Absolute changes in the retrieved cloud properties for the 127 OMI pixels by neglecting (a) AOD, (b) aerosol scattering, and (c) aerosol absorption. The criteria for pixel selection are presented in Sect. 2.4. The number of pixels is smaller for cloud pressure because cloud fraction is 0 in some pixels. Also shown are the statistics from the RMA regression; the dashed line indicates the regression curve.

of retrieved $\mathrm{NO}_{2}$ columns due to the effect of its vertical profile alone.

\subsection{Effects of aerosol optical effects}

Aerosol optics affect the retrievals of cloud properties and $\mathrm{NO}_{2}$ columns (Boersma et al., 2004, 2011; Leitão et al., 2010). In retrieving the cloud information, aerosol scattering enhances the $\mathrm{R}_{\mathrm{TOA}}$, thus reducing the $\mathrm{CF}$ (Fig. 5). It increases the AMF of $\mathrm{O}_{2}-\mathrm{O}_{2}$ with a negative effect on the CP. Aerosol scattering also enhances the AMF of $\mathrm{NO}_{2}$ when aerosols are collocated with or located below $\mathrm{NO}_{2}$. Aerosol absorption has opposite effects by enhancing the $\mathrm{CF}$ and $\mathrm{CP}$ and reducing the AMF of $\mathrm{NO}_{2}$. Furthermore, the height of aerosols is important for their influences on the $R_{\mathrm{TOA}}$ and on the AMFs of $\mathrm{O}_{2}-\mathrm{O}_{2}$ and $\mathrm{NO}_{2}$. Scattering aerosols located above $\mathrm{NO}_{2}$ will attenuate the radiation reaching $\mathrm{NO}_{2}$ (i.e., acting like clouds) with a negative effect on the AMF of $\mathrm{NO}_{2}$, as opposed to if scattering aerosols are below or collocated with
$\mathrm{NO}_{2}$. When a given amount of absorbing aerosols are lifted to higher altitudes, their absorption effect is enhanced.

Section 5.3.1 evaluates the effects of aerosol scattering and absorption in retrieving clouds and $\mathrm{NO}_{2}$ based on the simulated vertical shape of aerosols (cases 12-14 in Table 4). Section 5.3.2 analyzes the influences of the vertical shape of aerosols, keeping the AOD and SSA unchanged (cases 15-17 in Table 4).

\subsubsection{Effects of aerosol scattering and absorption based on the simulated vertical shape of aerosols}

Compared to the reference retrieval, case 12 does not include the optical effects of aerosols, as is done in the retrieval processes of OMCLDO2 and DOMINO-2. As shown in Fig. 6a, the exclusion of aerosols enhances the CFs (left panel) and CRFs (right panel) by implicitly interpreting aerosols as additional clouds. The CF increases by about 0.1 for a unity of AOD decremented (left panel). A modest correlation is found $\left(R^{2}=0.66\right)$ between the amounts of decremented AOD and 

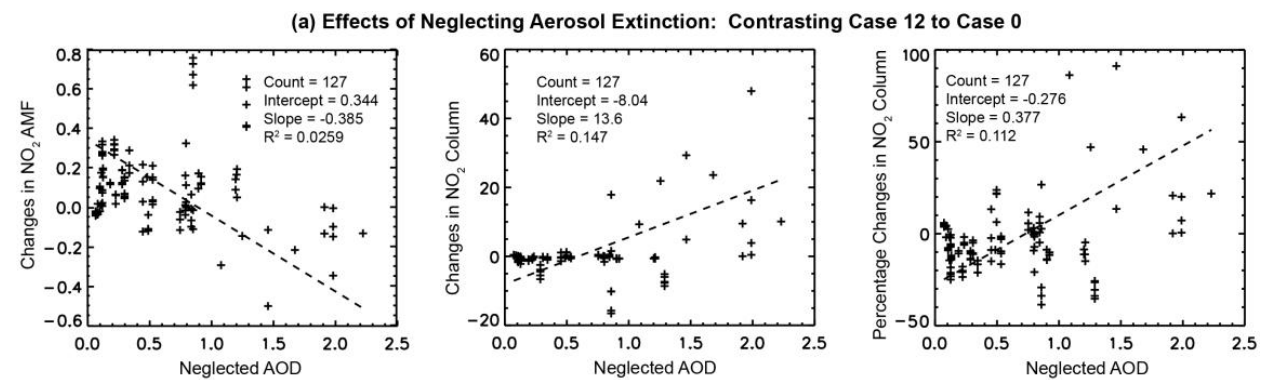

(b) Effects of Neglecting Aerosol Scattering: Contrasting Case 12 to Case 13
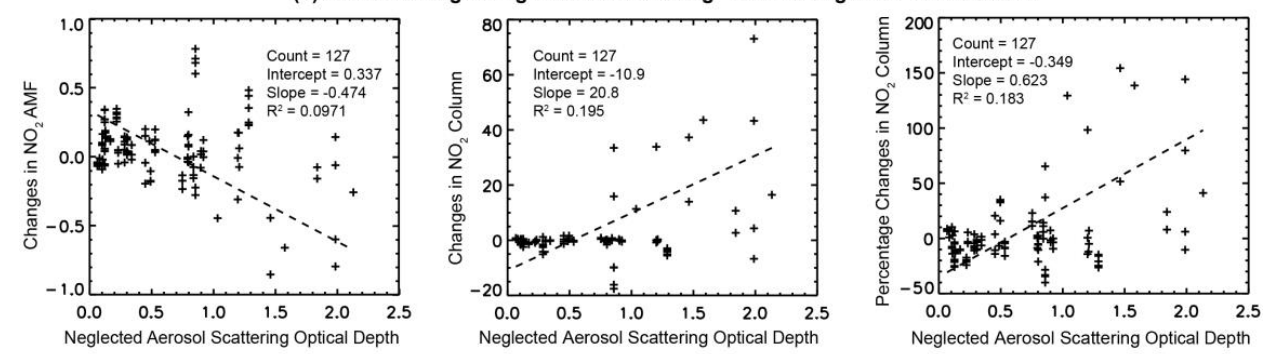

(c) Effects of Neglecting Aerosol Absorption: Contrasting Case 13 to Case 0
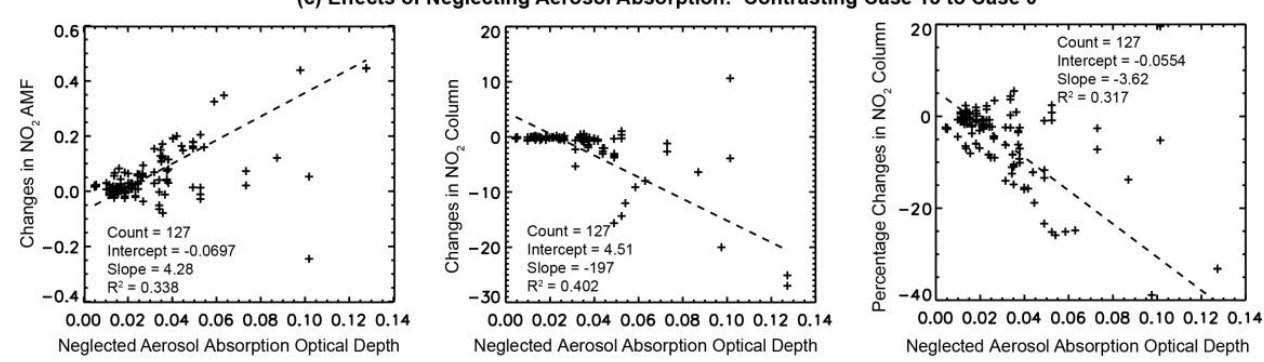

Fig. 7. Similar to Fig. 6 but for the absolute changes in the AMF of $\mathrm{NO}_{2}$ (left column) and the absolute (middle column) and percentage (right column) changes in the $\mathrm{VCD}$ of $\mathrm{NO}_{2}$.

the amounts of incremented $\mathrm{CF}$, and there is large scattering in the increments of $\mathrm{CF}$ when AOD exceeds 1.0. The changes in CP do not correlate with the amounts of decremented AOD ( $R^{2}=0.10$, middle panel), due to the compensating effect of excluding aerosol absorption versus excluding aerosol scattering. These results suggest complex effects of aerosol optical characteristics on the cloud retrieval. Comparisons of the cloud properties between case 12 and DOMINO-2 (OMCLDO2) are presented in Appendix D.

Figure 7a shows the effects of excluding aerosols on the retrieved $\mathrm{NO}_{2}$ in case 12 . As discussed above, aerosols affect both the cloudy-sky and clear-sky AMFs of $\mathrm{NO}_{2}$. Moreover, aerosol scattering and absorption lead to different effects on the radiation fields relevant to the AMFs of both $\mathrm{O}_{2}-\mathrm{O}_{2}$ and $\mathrm{NO}_{2}$. Thus, the exclusion of both aerosol scattering and absorption has large and complex impacts on the retrieved $\mathrm{NO}_{2}$ columns for individual pixels, particularly when AOD is high. Of the 44 pixels with AOD of 0.8 or more, case 12 results in larger $\mathrm{NO}_{2}$ columns than the reference retrieval by $0-50 \times 10^{15}$ molec $\mathrm{cm}^{-2}$ for 18 pixels, with negative effects by $0-20 \times 10^{15} \mathrm{molec} \mathrm{cm}^{-2}$ for the other 26 pixels (mid- dle panel). The percentage changes in $\mathrm{NO}_{2}$ columns are as large as $-40-90 \%$ for the 44 pixels (right panel). Compared to the reference retrieval, assuming no aerosol optical effects in case 12 leads to a smaller mean bias relative to MAXDOAS $\mathrm{NO}_{2}$ data (NMB decreases from $-46 \%$ to $-39 \%$ ) with lowered capability in capturing the day-to-day variability of MAX-DOAS $\mathrm{NO}_{2}\left(R^{2}\right.$ decreases from 0.96 to 0.90$)$.

The capability of aerosols to absorb solar radiation is determined mainly by black carbon. Emissions of black carbon in China have been under debate recently (Fu et al., 2012; Wang et al., 2013). The top-down constraint by Fu et al. (2012) suggested Chinese black carbon emissions to be underestimated by about $60 \%$ by the INTEX-B inventory. In contrast, Wang et al. (2013) suggested consistent magnitudes of emissions between their top-down calculation and the INTEX-B data after filtering out high pollution plumes and large precipitation events (for which cases they determined that the CTM was limited by model resolution and wet deposition errors). In light of these studies, we test the effects of aerosol absorption in retrieving clouds and $\mathrm{NO}_{2}$ by excluding or doubling the absorption in cases 13 and 14 , 
respectively. Assuming no aerosol absorption in case 13 reduces the amounts of CF and CRF (Fig. 6c). It leads to reduced $\mathrm{NO}_{2}$ columns in many but not all pixels (Fig. 7c), with a NMB of $-54 \%$ relative to MAX-DOAS $\mathrm{NO}_{2}$. Doubling aerosol absorption in case 14 has opposite effects on the retrieved clouds and $\mathrm{NO}_{2}$.

Figures $6 \mathrm{~b}$ and $7 \mathrm{~b}$ further present the sole effect of aerosol scattering by contrasting case 12 (neglecting both scattering and absorption) to case 13 (neglecting absorption). Neglecting aerosol scattering is compensated by increases in CF and CRF (Fig. 6b) with high correlation: $R^{2}=0.84(0.82)$ for the incremented CFs (CRFs) against the amounts of decremented scattering. This is consistent with the analysis by Boersma et al. (2011) for the southeastern US. The changes in CP do not correlate with the amounts of aerosol scattering omitted (Fig. 6b). Furthermore, Fig. 7b shows that neglecting aerosol scattering can either increase or decrease the retrieved $\mathrm{NO}_{2}$ columns, with no obvious dependence on the amounts of aerosol scattering neglected $\left(R^{2}<0.20\right.$ and the percentage changes range from $-40 \%$ to $+160 \%$ ). This is because aerosol scattering increases the absorption both by black carbon and by $\mathrm{NO}_{2}$ with compensating effects on the AMFs of $\mathrm{NO}_{2}$ (Lin et al., 2012). Also, aerosol scattering affects the AMFs of $\mathrm{NO}_{2}$ indirectly through its impacts on cloud fraction and cloud pressure. (Depending on the cloud pressure, the existence of clouds can either increase or decrease AMFs of $\mathrm{NO}_{2}$.) Our results suggest complex influences of aerosol scattering on the $\mathrm{NO}_{2}$ retrieval.

\subsubsection{Effects of the vertical shape of aerosols under given AOD and SSA}

The MAX-DOAS sites are located in urban or suburban areas; therefore aerosols and $\mathrm{NO}_{2}$ are dominated by anthropogenic sources and are collocated in the lower troposphere. Figure $3 \mathrm{c}$ illustrates the vertical distributions of aerosol EC and SSA assumed in the reference retrieval for a pixel on 28 December 2008. Cases 15-17 test the influences of the vertical shape of aerosols on the retrievals of clouds and $\mathrm{NO}_{2}$ without altering AOD and SSA (Table 4).

Case 15 assumes constant EC and SSA of aerosols throughout the troposphere as an extreme situation for the vertical distribution of aerosols. It enhances both scattering and absorption of aerosols at high altitudes, thus reducing the AMF of $\mathrm{O}_{2}-\mathrm{O}_{2}$ that is compensated for by an increase in CP. This case increases the CFs for $71 \%$ of the pixels in compensating for the effect of enhanced aerosol absorption on the $R_{\mathrm{TOA}}$. Overall, putting more aerosols above $\mathrm{NO}_{2}$ enhances the retrieved $\mathrm{NO}_{2}$ columns with a $\mathrm{NMB}$ of $-32 \%$ relative to MAX-DOAS.

Case 16 puts all aerosols at the PBL top, thus lowering the contributions of $\mathrm{O}_{2}-\mathrm{O}_{2}$ and $\mathrm{NO}_{2}$ in the PBL. It increases the $\mathrm{CFs}$ for half of the pixels with negative effects for one-third of the pixels, due to the competing effects of aerosol scattering and absorption. Compared to the reference retrieval, case 16 increases the retrieved $\mathrm{NO}_{2}$ columns with a reduction in NMB relative to MAX-DOAS (from $-46 \%$ to $-39 \%$ ). Putting all aerosols to the tropopause (case 17) further reduces the NMB to $-29 \%$; this test acts as another extreme case for analyzing the effect of aerosol vertical shape on the $\mathrm{NO}_{2}$ retrieval. The artificial adjustments in aerosol vertical shape in cases 16 and 17 significantly reduce the correlation to MAX-DOAS $\mathrm{NO}_{2}$ data (Table 4).

\subsection{Summary of sensitivity tests and consistency between OMI and MAX-DOAS $\mathrm{NO}_{2}$}

That our reference retrieval captures the day-to-day variability of MAX-DOAS $\mathrm{NO}_{2}$ much better than DOMINO-2 $\left(R^{2}=0.96\right.$ versus 0.72$)$ is caused by multiple factors. The largest contribution comes from the pixel-specific RTM calculation in place of the use of a LUT $\left(R^{2}\right.$ increases from 0.72 to 0.85 ; see Sect. 4 and Appendix C). Additional improvements are derived from the inclusion of aerosol optical effects $\left(R^{2}\right.$ decreases by 0.06 when excluding aerosols, case $12)$ and surface reflectance anisotropy $\left(R^{2}\right.$ decreases by 0.03 when adopting the OMI albedo instead of the MODIS BRDF, case 6). Changes in vertical profile of $\mathrm{NO}_{2}$ alone do not affect the correlation significantly for the OMI data analyzed here (case 8). There may be nonlinear interactions between the effects of these individual factors affecting the overall retrieval results.

Our reference retrieval leads to lower $\mathrm{NO}_{2}$ columns than MAX-DOAS by $46 \%$ on average. The difference is caused largely by the inevitable spatial inconsistency between OMI and MAX-DOAS measurements (effects roughly estimated at $20-30 \%$ ). This factor can be weakened in future studies using MAX-DOAS measurements taken at places with a more homogeneous horizontal distribution of $\mathrm{NO}_{2}$ (e.g., rural areas). Other possible factors include errors in MAXDOAS measurements (by 11-14\%; Irie et al., 2012; Hendrick et al., 2013) and uncertainties in our reference retrieval associated with SSA of aerosols (by $15 \%$ based on cases $13-$ 14 ), vertical distribution of aerosols (by $15 \%$ based on case 16), and vertical profile of $\mathrm{NO}_{2}$ (by $10-20 \%$ based on cases $7-8)$. The uncertainties in a given parameter may also influence the importance of other parameters in retrieving $\mathrm{NO}_{2}$.

On average, the magnitude of $\mathrm{NO}_{2}$ columns in DOMINO2 is higher than our reference retrieval by $76 \%$ and is close to MAX-DOAS. This is caused in part by a significant overestimate in surface pressure adopted in DOMINO-2 (the effect is estimated at $25 \%$ in Sect. 4). The higher $\mathrm{NO}_{2}$ columns in DOMINO-2 are contributed also by the exclusion of aerosols (effect at $14 \%$, case 12), a stronger vertical gradient of $\mathrm{NO}_{2}$ (effect at $13 \%$, case 8), and possibly the use of a DAK-based LUT (effect at $4 \%$, case 1 ). 


\section{Conclusions}

Based on LIDORT v3.6, we improved the AMF calculation ("AMFv6" code) in order to retrieve VCDs of tropospheric $\mathrm{NO}_{2}$ from OMI and to evaluate the effects of aerosols, surface reflectance anisotropy, and vertical profile of $\mathrm{NO}_{2}$ in the retrieval process. To derive the VCDs, our reference retrieval calculated the AMFs of $\mathrm{NO}_{2}$ independently after adopting the tropospheric SCDs from the widely used DOMINO-2 product. We retrieved the cloud properties prior to the retrieval of $\mathrm{NO}_{2}$ using consistent ancillary parameters including but not limited to surface pressure, surface reflectance, and aerosols. We accounted for surface reflectance anisotropy by adopting the MODIS BRDF data. We used vertical profiles of $\mathrm{NO}_{2}$ simulated by the nested GEOSChem model. Also, we explicitly accounted for the effect of aerosols on the solar radiation during the retrieval process by incorporating aerosol information from GEOS-Chem simulations and observations.

We compared DOMINO-2 to our $\mathrm{NO}_{2}$ retrieval, using the ground-based MAX-DOAS measurements at three urban/suburban sites in East China as reference and focusing on the 127 OMI pixels in 30 days complying with our spatial constraints (pixel-center distance $\leq 25 \mathrm{~km}, \mathrm{VZA} \leq 30^{\circ}$ ). Compared to DOMINO-2, our reference retrieval better captures the day-to-day variability in MAX-DOAS $\mathrm{NO}_{2}\left(R^{2}=\right.$ 0.96 versus 0.72 for the 30 days). This is due to the LIDORTbased pixel-specific radiative transfer calculations instead of interpolation from a DAK-derived LUT $\left(R^{2}\right.$ increases by $0.13)$, the explicit inclusion of aerosols $\left(R^{2}\right.$ increases by $0.06)$, the inclusion of surface reflectance anisotropy $\left(R^{2}\right.$ increases by 0.03 ), and the potential interactions between the effects of these factors.

Our reference retrieval leads to $\mathrm{NO}_{2}$ columns about $54 \%$ of MAX-DOAS data on average. The difference is due to the inevitable spatial inconsistency between the ground- and space-based remote sensing (by 20-30\%, a rough estimate), errors in MAX-DOAS measurements (by 11-14\%), and uncertainties in our $\mathrm{OMI} \mathrm{NO}_{2}$ retrieval associated with aerosols (SSA and vertical distribution, by $15 \%$ each) and vertical shape of $\mathrm{NO}_{2}$ (by 10-20\%). The magnitude of $\mathrm{NO}_{2}$ columns retrieved by DOMINO-2 is closer to the MAX-DOAS measurements, due in part to the overestimate in surface pressure, the exclusion of aerosols, a stronger vertical gradient of $\mathrm{NO}_{2}$, and possibly the adoption of a DAK-based LUT in the retrieval process. Note that our estimate for the effect of spatial inconsistency is preliminary since the spatial inhomogeneity of $\mathrm{NO}_{2}$ strongly depends on the locations, time, and meteorological conditions (Brinksma et al., 2008; Irie et al., 2012; Ma et al., 2013). Comparisons with MAX-DOAS measurements and $\mathrm{NO}_{2}$ sondes (Sluis et al., 2010) in places with a more homogenous distribution of $\mathrm{NO}_{2}$ will be less subject to the effect of spatial inconsistency, and will help separate the effects of individual ancillary assumptions in retrieving $\mathrm{NO}_{2}$.
When excluding aerosols in the cloud retrieval, the increase in retrieved cloud fraction is highly correlated to the amount of aerosol scattering omitted $\left(R^{2}=0.84\right)$. However, the effect of omitting aerosol scattering on retrieved cloud pressure and the effect of omitting aerosol absorption on both cloud fraction and cloud pressure are complex and nonlinear. Compared to DOMINO-2, the inclusion of aerosols increases the number of valid OMI pixels with low cloud coverage (CRF $\leq 50 \%$, the criterion for cloud screening) by about $25 \%$ for the data set investigated here.

In retrieving $\mathrm{NO}_{2}$, the inclusion or exclusion of aerosol optical effects results in very different AMFs and VCDs of tropospheric $\mathrm{NO}_{2}$ for individual pixels. Particularly when AOD exceeds 0.8 , the retrieved $\mathrm{NO}_{2}$ columns differ by $-70-90 \%$ with versus without the inclusion of aerosols. This supports a better treatment of aerosols in retrieving $\mathrm{NO}_{2}$, with important implications for further applications such as emission inversion at fine spatial or temporal scales. Meanwhile, the difference is about $14 \%$ for the 30 -day average $\mathrm{NO}_{2}$ column with or without explicitly accounting for aerosols in the retrieval process, suggesting that the effect of aerosols may be reduced by spatiotemporal averaging.

Adopting the vertical shape of $\mathrm{NO}_{2}$ from TM4 or MAXDOAS increases the retrieved $\mathrm{NO}_{2}$ columns by $13-19 \%$ on average. This sensitivity calls for a better representation of $\mathrm{NO}_{2}$ vertical profile in the retrieval process. In addition, a variety of assumptions on surface reflectance (e.g., MODIS BRDF, MODIS black-sky or blue-sky albedo, and OMI albedo) lead to similar $\mathrm{NO}_{2}$ columns on average (within $10 \%$ ). This reflects the compensation between the direct effect of surface reflectance errors in retrieving $\mathrm{NO}_{2}$ and its indirect impact through the cloud retrieval for the OMI pixels investigated here. Zhou et al. (2010) suggested larger sensitivity of the $\mathrm{NO}_{2}$ retrieval to surface reflectance data over Europe.

As a concluding remark, the effects of aerosols and surface reflectance anisotropy found here also have important implications for retrievals of other species (sulfur dioxide, formaldehyde, glyoxal, etc.) from OMI and/or other UVvisible backscatter instruments. We recommend that aerosols and surface reflectance anisotropy be explicitly accounted for in future satellite retrievals, especially when a near-real-time retrieval (fast computation) is not required, so that these factors can be well characterized for individual pixels in the retrieval process without the use of a LUT. Aerosol information can be adopted from observations or model simulations (especially after constrained by independent measurements). Even when accurate aerosol information is not available, a retrieval that explicitly accounts for the effects of aerosols can provide an alternate product for comparisons with a nearreal-time product with no explicit consideration of aerosols. In addition, we suggest using high-resolution vertical profiles of tracers in the retrieval process to better characterize their spatial inhomogeneity. 

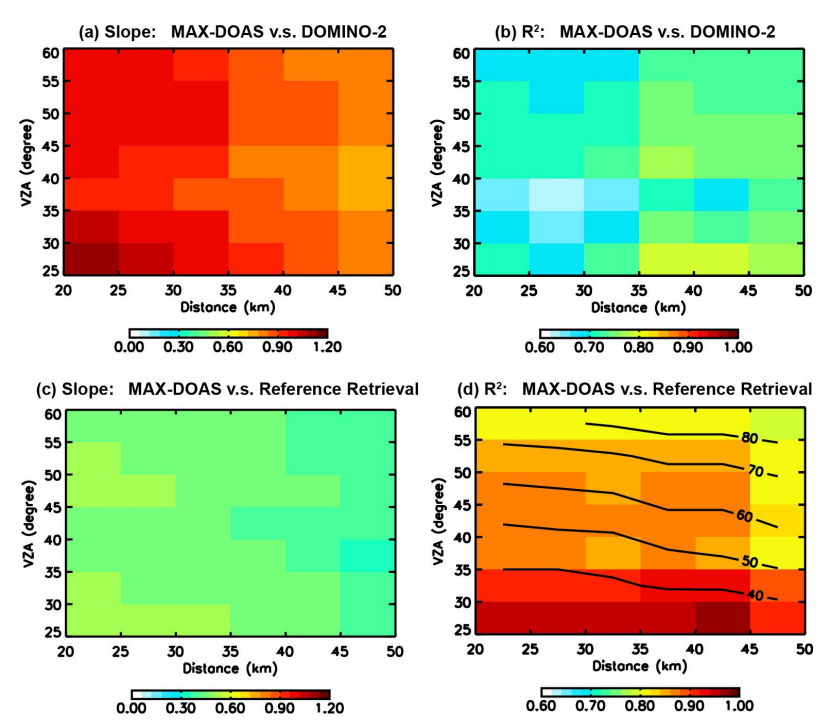

Fig. A1. Dependence on pixel-center distance and VZA of the RMA regression (slope and $R^{2}$ ) for the daily $\mathrm{NO}_{2}$ columns between MAX-DOAS and OMI retrievals. The lower left tile in each panel represents distance $\leq 25 \mathrm{~km}$ and $\mathrm{VZA} \leq 30^{\circ}$. The rest of the criteria for pixel selection are unchanged (row-anomaly-free, ice/snow-free, $\mathrm{CRF} \leq 0.5$ ). Overlaid on (d) is the number of days with suitable $\mathrm{NO}_{2}$ data for conducting the RMA regression.

\section{Appendix A}

\section{GEOS-Chem modeling}

We used the nested GEOS-Chem model for Asia (v8-3-2; Chen et al., 2009), at $0.667^{\circ}$ long. $\times 0.5^{\circ}$ lat. with 47 layers, to simulate vertical profiles of $\mathrm{NO}_{2}$ and aerosol optical properties. The model is driven by the GEOS- 5 assimilated meteorological fields from the NASA Global Modeling and Assimilation Office (GMAO). It is run with the full $\mathrm{O}_{\mathrm{x}}-$ $\mathrm{NO}_{\mathrm{x}}-\mathrm{VOC}-\mathrm{CO}-\mathrm{HO}_{\mathrm{x}}$ gaseous chemistry with online aerosol calculations. Vertical mixing in the planetary boundary layer is simulated by a nonlocal parameterization scheme (Lin and McElroy, 2010). The simulation of convection is based on a modified relaxed Arakawa-Schubert scheme (Rienecker et al., 2008). Asian anthropogenic emissions are taken from the INTEX-B data set (Zhang et al., 2009). Lightning emissions of NOx follow Price et al. (1997) with a local correction based on the OTD/LIS satellite measurements (Sauvage et al., 2007; Murray et al., 2012), and are distributed vertically with a backward "C-shape" profile (Ott et al., 2010). Soil emissions of $\mathrm{NO}_{\mathrm{x}}$ follow Yienger and Levy (1995) and Wang et al. (1998). More model descriptions can be found in Lin (2012) and Lin et al. (2012).

For aerosols, GEOS-Chem simulate sulfates, nitrates, ammoniums (Park et al., 2004, 2006), black carbon, organic carbon (Park et al., 2003, 2006), dust (Fairlie et al., 2010), and sea salts (Alexander et al., 2005; Jaeglé et al., 2011).
The general structure of the aerosol simulations is presented by Park et al. (2004, 2006). The sulfate-nitrate-ammonium aerosols are simulated by the thermodynamical equilibrium scheme of ISOROPIA-II (Fountoukis and Nenes, 2007). Emissions of mineral dusts adopt the DEAD scheme (Zender et al., 2003). Aerosol microphysical properties follow Drury et al. (2010), including dry size distributions, hygroscopic growth factors, and refractive indices.

\section{Appendix B \\ On the spatial consistency between MAX-DOAS and OMI data}

Figure A1 shows the dependence of the consistency between daily OMI and MAX-DOAS data on the spatial constraints by pixel-center distance (from $25 \mathrm{~km}$ to $50 \mathrm{~km}$ ) and VZA (from $30^{\circ}$ to unlimited). For both DOMINO-2 and our reference retrieval, loosening the distance constraint results in a monotonic reduction in the slope (from the RMA regression) with respect to the MAX-DOAS data (Fig. A1a, c). With a given VZA constraint, the slope reduces by $0.09-0.31$ from distance $\leq 25 \mathrm{~km}$ to distance $\leq 50 \mathrm{~km}$. This indicates that $\mathrm{NO}_{2}$ measured by MAX-DOAS (mostly at IAP) represents a local maximum. The findings here are consistent with those by Irie et al. (2012) for the polluted Yokosuka site in Japan. Varying the VZA constraint does not lead to a monotonic change in the slope, since the spatial coverage of a pixel also varies.

For our reference retrieval, the RMA slope varies from 0.36 to 0.51 across the range of the spatial constraints, and is consistently smaller than the slope for DOMINO-2 (0.741.10). As detailed in Sects. 4, 5.2, and 5.3, the higher RMA slope for DOMINO-2 is due in part to the overestimate in surface pressure, the exclusion of aerosols, the stronger vertical gradient of $\mathrm{NO}_{2}$, and possibly the adoption of a DAKderived LUT in the retrieval process. In addition, our reference retrieval captures the day-to-day variability of MAXDOAS $\mathrm{NO}_{2}$ much better than DOMINO-2 $\left(R^{2}=0.78-0.96\right.$ versus 0.63-0.79; Fig. A1b, d).

\section{Appendix C}

\section{Pixel-specific LIDORT calculation versus DAK-derived LUT}

Some differences exist between LIDORT and DAK. LIDORT assumes no polarization of light with a curved atmosphere, while DAK accounts for polarization in a parallel atmosphere. Compared to LIDORT, use of DAK leads to larger $\mathrm{NO}_{2}$ columns by $1-5 \%$ averaged over China (Huan et al., 2013).

Furthermore, the use of a LUT in DOMINO-2 involves the projection of layer AMFs from the pressure coordinate 

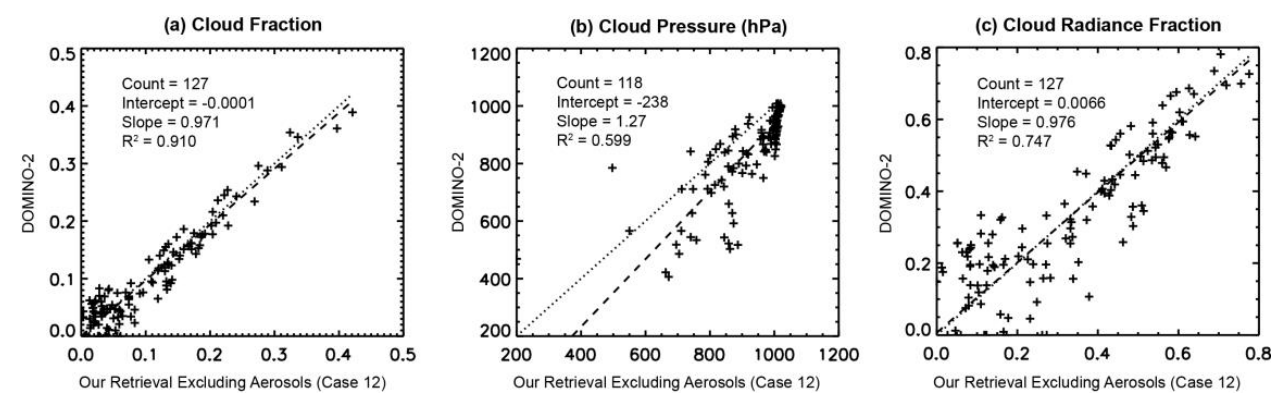

Fig. A2. Scatter plots between DOMINO-2 ( $y$ axis) and our case 12 (assuming no aerosols, $x$ axis) for cloud properties across the individual pixels. DOMINO-2 adopts cloud fraction and cloud pressure from OMCLDO2. The criteria for pixel selection are presented in Sect. 2.4. The number of pixels is smaller for cloud pressure because cloud fraction is 0 in some pixels. Also shown are the statistics from the RMA regression; the dashed line indicates the regression curve and the dotted line denotes the $1: 1$ relationship.

of TM4 (with 34 layers) to the coordinate assumed in the LUT (with 24 layers). The projection introduces certain errors due to the large vertical variability in the layer AMFs (e.g., Fig. 3a). Our AMF calculation adopted the TM4 pressure coordinate with no need of a coordinate projection. A LUT also means that layer AMFs are obtained by linear interpolation based on various parameters (As, Ps, CF, CP, and light path geometry), as opposed to our pixel-specific RTM simulations. Further research is required to quantify the effects of these individual factors.

\section{Appendix D}

Retrieval of cloud properties assuming no aerosols: our retrieval versus DOMINO-2 (OMCLDO2)

Our case 12 assumes no aerosols with consequences on the retrieved cloud properties. Figure A2 shows that the CRFs in case 12 are close to those in DOMINO-2, and that the CFs in case 12 are similar to OMCLDO2 averaged over all pixels. However, notable differences exist for individual pixels, due to differences in surface reflectance, pressure and temperature profiles, RTMs, and whether or not to use a LUT (Tables 2 and 3 and Appendix C).

The $\mathrm{CP}$ produced by case 12 is larger than OMCLDO2 (Fig. A2). The difference is not caused by the different Ps data used according to our test cloud retrieval adopting the Ps data from OMCLDO2. Further research is needed to determine the causes of the difference.

Acknowledgements. This research is supported by the National Natural Science Foundation of China, grant 41005078, 41175127 and 41175030, and by the 973 program, grant 2014CB441303. We thank Huan Yu and Dominik Brunner for discussions on the radiative transfer modeling. We acknowledge the free use of $\mathrm{NO}_{2}$ and cloud products from www.temis.nl, surface elevation data from USGS, MODIS aerosol and surface reflectance data from NASA, and AOD measurements from AERONET. MAX-DOAS measure- ments in Beijing and Xianghe have been supported through the EU FP7 project NORS and by the Belgian Science Policy (IBBAC contract BL/35/C60, and AGACC project, grant SD/CS/07A). Folkert Boersma acknowledges support from the NWO Vidi-grant 864.09.001.

Edited by: G. Carmichael

\section{References}

Acarreta, J. R., De Haan, J. F., and Stammes, P.: Cloud pressure retrieval using the O-2-O-2 absorption band at $477 \mathrm{~nm}$, J. Geophys. Res.-Atmos., 109, D05204, doi:10.1029/2003jd003915, 2004.

Alexander, B., Park, R. J., Jacob, D. J., Li, Q. B., Yantosca, R. M., Savarino, J., Lee, C. C. W., and Thiemens, M. H.: Sulfate formation in sea-salt aerosols: Constraints from oxygen isotopes, J. Geophys. Res.-Atmos., 110, D10307, doi:10.1029/2004jd005659, 2005.

Anderson, G. P., Clough, S. A., Kneizys, F. X., Chetwynd, J. H., and Shettle, E. P.: AFGL Atmospheric Constituent Profiles, Air Force Geophys. Lab., Hanscom AFB, Mass., Tech. Rep. AFGLTR-86-0110, 1986.

Beirle, S., Boersma, K. F., Platt, U., Lawrence, M. G., and Wagner, T.: Megacity Emissions and Lifetimes of Nitrogen Oxides Probed from Space, Science, 333, 1737-1739, doi:10.1126/science.1207824, 2011.

Boersma, K. F., Eskes, H. J., and Brinksma, E. J.: Error analysis for tropospheric $\mathrm{NO}_{2}$ retrieval from space, J. Geophys. Res., 109, D04311, doi:10.1029/2003JD003962, 2004.

Boersma, K. F., Eskes, H. J., Veefkind, J. P., Brinksma, E. J., van der A, R. J., Sneep, M., van den Oord, G. H. J., Levelt, P. F., Stammes, P., Gleason, J. F., and Bucsela, E. J.: Near-real time retrieval of tropospheric $\mathrm{NO}_{2}$ from OMI, Atmos. Chem. Phys., 7, 2103-2118, doi:10.5194/acp-7-2103-2007, 2007.

Boersma, K. F., Eskes, H. J., Dirksen, R. J., van der A, R. J., Veefkind, J. P., Stammes, P., Huijnen, V., Kleipool, Q. L., Sneep, M., Claas, J., Leitão, J., Richter, A., Zhou, Y., and Brunner, D.: An improved tropospheric $\mathrm{NO}_{2}$ column retrieval algorithm for the Ozone Monitoring Instrument, Atmos. Meas. Tech., 4, 19051928, doi:10.5194/amt-4-1905-2011, 2011. 
Brinksma, E. J., Pinardi, G., Volten, H., Braak, R., Richter, A., Schonhardt, A., van Roozendael, M., Fayt, C., Hermans, C., Dirksen, R. J., Vlemmix, T., Berkhout, A. J. C., Swart, D. P. J., Oetjen, H., Wittrock, F., Wagner, T., Ibrahim, O. W., de Leeuw, G., Moerman, M., Curier, R. L., Celarier, E. A., Cede, A., Knap, W. H., Veefkind, J. P., Eskes, H. J., Allaart, M., Rothe, R., Piters, A. J. M., and Levelt, P. F.: The 2005 and 2006 DANDELIONS $\mathrm{NO}_{2}$ and aerosol intercomparison campaigns, J. Geophys. Res.Atmos., 113, D16S46, doi:10.1029/2007jd008808, 2008.

Bucsela, E. J., Perring, A. E., Cohen, R. C., Boersma, K. F., Celarier, E. A., Gleason, J. F., Wenig, M. O., Bertram, T. H., Wooldridge, P. J., Dirksen, R., and Veefkind, J. P.: Comparison of tropospheric $\mathrm{NO}_{2}$ from in situ aircraft measurements with near-real-time and standard product data from OMI, J. Geophys. Res.-Atmos., 113, D16s31, doi:10.1029/2007jd008838, 2008.

Bucsela, E. J., Krotkov, N. A., Celarier, E. A., Lamsal, L. N., Swartz, W. H., Bhartia, P. K., Boersma, K. F., Veefkind, J. P., Gleason, J. F., and Pickering, K. E.: A new stratospheric and tropospheric $\mathrm{NO}_{2}$ retrieval algorithm for nadir-viewing satellite instruments: applications to OMI, Atmos. Meas. Tech., 6, 26072626, doi:10.5194/amt-6-2607-2013, 2013.

Castellanos, P. and Boersma, K. F.: Reductions in nitrogen oxides over Europe driven by environmental policy and economic recession, Sci. Rep., 2, 265, doi:10.1038/srep00265, 2012.

Chen, D., Wang, Y., McElroy, M. B., He, K., Yantosca, R. M., and Le Sager, P.: Regional CO pollution and export in China simulated by the high-resolution nested-grid GEOS-Chem model, Atmos. Chem. Phys., 9, 3825-3839, doi:10.5194/acp-9-3825-2009, 2009.

Cheng, Z., Jiang, J. K., Fajardo, O., Wang, S. X., and Hao, J. M.: Characteristics and health impacts of particulate matter pollution in China (2001-2011), Atmos. Environ., 65, 186-194, doi:10.1016/j.atmosenv.2012.10.022, 2013.

Clémer, K., Van Roozendael, M., Fayt, C., Hendrick, F., Hermans, C., Pinardi, G., Spurr, R., Wang, P., and De Mazière, M.: Multiple wavelength retrieval of tropospheric aerosol optical properties from MAXDOAS measurements in Beijing, Atmos. Meas. Tech., 3, 863-878, doi:10.5194/amt-3-863-2010, 2010.

Dieudonné, E., Ravetta, F., Pelon, J., Goutail, F., and Pommereau, J.-P.: Linking $\mathrm{NO}_{2}$ surface concentration and integrated content in the urban developed atmospheric boundary layer, Geophys. Res. Lett., 40, 1247-1251, doi:10.1002/grl.50242, 2013.

Drury, E., Jacob, D. J., Spurr, R. J. D., Wang, J., Shinozuka, Y., Anderson, B. E., Clarke, A. D., Dibb, J., McNaughton, C., and Weber, R.: Synthesis of satellite (MODIS), aircraft (ICARTT), and surface (IMPROVE, EPA-AQS, AERONET) aerosol observations over eastern North America to improve MODIS aerosol retrievals and constrain surface aerosol concentrations and sources, J. Geophys. Res.-Atmos., 115, D14204, doi:10.1029/2009jd012629, 2010.

Fairlie, T. D., Jacob, D. J., Dibb, J. E., Alexander, B., Avery, M. A., van Donkelaar, A., and Zhang, L.: Impact of mineral dust on nitrate, sulfate, and ozone in transpacific Asian pollution plumes, Atmos. Chem. Phys., 10, 3999-4012, doi:10.5194/acp-10-39992010, 2010.

Ford, B. and Heald, C. L.: An A-train and model perspective on the vertical distribution of aerosols and $\mathrm{CO}$ in the Northern Hemisphere, J. Geophys. Res.-Atmos., 117, D06211, doi:10.1029/2011jd016977, 2012.
Fountoukis, C. and Nenes, A.: ISORROPIA II: a computationally efficient thermodynamic equilibrium model for $\mathrm{K}^{+}$$\mathrm{Ca}^{2+}-\mathrm{Mg}^{2+}-\mathrm{NH}_{4}^{+}-\mathrm{Na}^{+}-\mathrm{SO}_{4}^{2-}-\mathrm{NO}_{3}^{-}-\mathrm{Cl}^{-}-\mathrm{H}_{2} \mathrm{O}$ aerosols, Atmos. Chem. Phys., 7, 4639-4659, doi:10.5194/acp-7-4639-2007, 2007.

Fu, T.-M., Cao, J. J., Zhang, X. Y., Lee, S. C., Zhang, Q., Han, Y. M., Qu, W. J., Han, Z., Zhang, R., Wang, Y. X., Chen, D., and Henze, D. K.: Carbonaceous aerosols in China: top-down constraints on primary sources and estimation of secondary contribution, Atmos. Chem. Phys., 12, 2725-2746, doi:10.5194/acp12-2725-2012, 2012.

Hains, J. C., Boersma, K. F., Kroon, M., Dirksen, R. J., Cohen, R. C., Perring, A. E., Bucsela, E., Volten, H., Swart, D. P. J., Richter, A., Wittrock, F., Schoenhardt, A., Wagner, T., Ibrahim, O. W., van Roozendael, M., Pinardi, G., Gleason, J. F., Veefkind, J. P., and Levelt, P.: Testing and improving OMI DOMINO tropospheric $\mathrm{NO}_{2}$ using observations from the DANDELIONS and INTEX-B validation campaigns, J. Geophys. Res.-Atmos., 115, D05301, doi:10.1029/2009jd012399, 2010.

Hendrick, F., Müller, J.-F., Clémer, K., De Mazière, M., Fayt, C., Hermans, C., Stavrakou, T., Vlemmix, T., Wang, P., and Van Roozendael, M.: Four years of ground-based MAX-DOAS observations of $\mathrm{HONO}$ and $\mathrm{NO}_{2}$ in the Beijing area, Atmos. Chem. Phys. Discuss., 13, 10621-10660, doi:10.5194/acpd-13-106212013, 2013.

Herman, J. R., Celarier, E., and Larko, D.: UV $380 \mathrm{~nm}$ reflectivity of the Earth's surface, clouds and aerosols, J. Geophys. Res.Atmos., 106, 5335-5351, doi:10.1029/2000jd900584, 2001.

Huan, Y., Van Roozendael, M., Wang, P., De Smedt, I., van Gent, J., van der A, R., Boersma, F., Valks, P., Richter, A., Stavrakou, T., and Müller, J.-F.: Intercomparison of tropospheric $\mathrm{NO}_{2}$ retrievals from the OMI and GOME-2 sensors over China, poster presentation at Living Planet Symposium Edinburgh, Edinburgh, 2013.

Hudman, R. C., Russell, A. R., Valin, L. C., and Cohen, R. C.: Interannual variability in soil nitric oxide emissions over the United States as viewed from space, Atmos. Chem. Phys., 10, 99439952, doi:10.5194/acp-10-9943-2010, 2010.

Hyer, E. J., Reid, J. S., and Zhang, J.: An over-land aerosol optical depth data set for data assimilation by filtering, correction, and aggregation of MODIS Collection 5 optical depth retrievals, Atmos. Meas. Tech., 4, 379-408, doi:10.5194/amt-4-379-2011, 2011.

Irie, H., Kanaya, Y., Akimoto, H., Tanimoto, H., Wang, Z., Gleason, J. F., and Bucsela, E. J.: Validation of OMI tropospheric $\mathrm{NO}_{2}$ column data using MAX-DOAS measurements deep inside the North China Plain in June 2006: Mount Tai Experiment 2006, Atmos. Chem. Phys., 8, 6577-6586, doi:10.5194/acp-8-6577-2008, 2008.

Irie, H., Takashima, H., Kanaya, Y., Boersma, K. F., Gast, L., Wittrock, F., Brunner, D., Zhou, Y., and Van Roozendael, M.: Eightcomponent retrievals from ground-based MAX-DOAS observations, Atmos. Meas. Tech., 4, 1027-1044, doi:10.5194/amt-41027-2011, 2011.

Irie, H., Boersma, K. F., Kanaya, Y., Takashima, H., Pan, X., and Wang, Z. F.: Quantitative bias estimates for tropospheric $\mathrm{NO}_{2}$ columns retrieved from SCIAMACHY, OMI, and GOME-2 using a common standard for East Asia, Atmos. Meas. Tech., 5, 2403-2411, doi:10.5194/amt-5-2403-2012, 2012. 
Jaeglé, L., Quinn, P. K., Bates, T. S., Alexander, B., and Lin, J.-T.: Global distribution of sea salt aerosols: new constraints from in situ and remote sensing observations, Atmos. Chem. Phys., 11, 3137-3157, doi:10.5194/acp-11-3137-2011, 2011.

Kleipool, Q. L., Dobber, M. R., de Haan, J. F., and Levelt, P. F.: Earth surface reflectance climatology from 3 years of OMI data, J. Geophys. Res.-Atmos., 113, D18308, doi:10.1029/2008jd010290, 2008.

Lamsal, L. N., Martin, R. V., van Donkelaar, A., Steinbacher, M., Celarier, E. A., Bucsela, E., Dunlea, E. J., and Pinto, J. P.: Ground-level nitrogen dioxide concentrations inferred from the satellite-borne Ozone Monitoring Instrument, J. Geophys. Res.Atmos., 113, D16308, doi:10.1029/2007jd009235, 2008.

Lamsal, L. N., Martin, R. V., Padmanabhan, A., van Donkelaar, A., Zhang, Q., Sioris, C. E., Chance, K., Kurosu, T. P., and Newchurch, M. J.: Application of satellite observations for timely updates to global anthropogenic $\mathrm{NO}(\mathrm{x})$ emission inventories, Geophys. Res. Lett., 38, L05810, doi:10.1029/2010g1046476, 2011.

Leitão, J., Richter, A., Vrekoussis, M., Kokhanovsky, A., Zhang, Q. J., Beekmann, M., and Burrows, J. P.: On the improvement of $\mathrm{NO}_{2}$ satellite retrievals - aerosol impact on the airmass factors, Atmos. Meas. Tech., 3, 475-493, doi:10.5194/amt-3-475-2010, 2010.

Lin, J.-T.: Satellite constraint for emissions of nitrogen oxides from anthropogenic, lightning and soil sources over East China on a high-resolution grid, Atmos. Chem. Phys., 12, 2881-2898, doi:10.5194/acp-12-2881-2012, 2012

Lin, J. T. and McElroy, M. B.: Impacts of boundary layer mixing on pollutant vertical profiles in the lower troposphere: Implications to satellite remote sensing, Atmos. Environ., 44, 17261739, doi:10.1016/j.atmosenv.2010.02.009, 2010.

Lin, J.-T. and McElroy, M. B.: Detection from space of a reduction in anthropogenic emissions of nitrogen oxides during the Chinese economic downturn, Atmos. Chem. Phys., 11, 8171-8188, doi:10.5194/acp-11-8171-2011, 2011.

Lin, J.-T., Nielsen, C. P., Zhao, Y., Lei, Y., Liu, Y., and McElroy, M. B.: Recent Changes in Particulate Air Pollution over China Observed from Space and the Ground: Effectiveness of Emission Control, Environ. Sci. Technol., 44, 7771-7776, doi:10.1021/es101094t, 2010a.

Lin, J.-T., McElroy, M. B., and Boersma, K. F.: Constraint of anthropogenic $\mathrm{NO}_{\mathrm{x}}$ emissions in China from different sectors: a new methodology using multiple satellite retrievals, Atmos. Chem. Phys., 10, 63-78, doi:10.5194/acp-10-63-2010, 2010b.

Lin, J.-T., Liu, Z., Zhang, Q., Liu, H., Mao, J., and Zhuang, G.: Modeling uncertainties for tropospheric nitrogen dioxide columns affecting satellite-based inverse modeling of nitrogen oxides emissions, Atmos. Chem. Phys., 12, 12255-12275, doi:10.5194/acp-12-12255-2012, 2012.

Lin, J.-T. et al.: Improved retrieval of the tropospheric $\mathrm{NO}_{2}$ seasonality from the Ozone Monitoring Instrument, in preparation, 2014.

Liu, J., Xia, X., Wang, P., Li, Z., Zheng, Y., Cribb, M., and Chen, H.: Significant aerosol direct radiative effects during a pollution episode in northern China, Geophys. Res. Lett., 34, L23808, doi:10.1029/2007g1030953, 2007.

Lucht, W., Schaaf, C. B., and Strahler, A. H.: An algorithm for the retrieval of albedo from space using semiempiri- cal BRDF models, Ieee T. Geosci. Remote, 38, 977-998, doi:10.1109/36.841980, 2000

Ma, J. Z., Beirle, S., Jin, J. L., Shaiganfar, R., Yan, P., and Wagner, T.: Tropospheric $\mathrm{NO}_{2}$ vertical column densities over Beijing: results of the first three years of ground-based MAX-DOAS measurements (2008-2011) and satellite validation, Atmos. Chem. Phys., 13, 1547-1567, doi:10.5194/acp-13-1547-2013, 2013.

Martin, R. V.: Satellite remote sensing of surface air quality, Atmos. Environ., 42, 7823-7843, doi:10.1016/j.atmosenv.2008.07.018, 2008.

Martin, R. V., Chance, K., Jacob, D. J., Kurosu, T. P., Spurr, R. J. D., Bucsela, E., Gleason, J. F., Palmer, P. I., Bey, I., Fiore, A. M., Li, Q. B., Yantosca, R. M., and Koelemeijer, R. B. A.: An improved retrieval of tropospheric nitrogen dioxide from GOME, J. Geophys. Res.-Atmos., 107, 4437, doi:10.1029/2001jd001027, 2002.

Martin, R. V., Jacob, D. J., Chance, K., Kurosu, T. P., Palmer, P. I., and Evans, M. J.: Global inventory of nitrogen oxide emissions constrained by space-based observations of $\mathrm{NO}_{2}$ columns, J. Geophys. Res., 108, 4537, doi:10.1029/2003JD003453, 2003.

Martin, R. V., Sioris, C. E., Chance, K., Ryerson, T. B., Bertram, T. H., Wooldridge, P. J., Cohen, R. C., J. Andy Neuman, Swanson, A., and Flocke, F. M.: Evaluation of space-based constraints on global nitrogen oxide emissions with regional aircraft measurements over and downwind of eastern North America, J. Geophys. Res., 111, D15308, doi:10.1029/2005JD006680, 2006.

Mebust, A. K., Russell, A. R., Hudman, R. C., Valin, L. C., and Cohen, R. C.: Characterization of wildfire $\mathrm{NO}_{\mathrm{x}}$ emissions using MODIS fire radiative power and OMI tropospheric $\mathrm{NO}_{2}$ columns, Atmos. Chem. Phys., 11, 5839-5851, doi:10.5194/acp11-5839-2011, 2011.

Mijling, B. and van der A, R. J.: Using daily satellite observations to estimate emissions of short-lived air pollutants on a mesoscopic scale, J. Geophys. Res.-Atmos., 117, D17302, doi:10.1029/2012jd017817, 2012.

Mijling, B., van der A, R. J., Boersma, K. F., Van Roozendael, M., De Smedt, I., and Kelder, H. M.: Reductions of $\mathrm{NO}_{2}$ detected from space during the 2008 Beijing Olympic Games, Geophys. Res. Lett., 36, D13801, doi:10.1029/2009g1038943, 2009.

Murray, L. T., Jacob, D. J., Logan, J. A., Hudman, R. C., and Koshak, W. J.: Optimized regional and interannual variability of lightning in a global chemical transport model constrained by LIS/OTD satellite data, J. Geophys. Res.-Atmos., 117, D20307, doi:10.1029/2012jd017934, 2012.

Novotny, E. V., Bechle, M. J., Millet, D. B., and Marshall, J. D.: National Satellite-Based Land-Use Regression: $\mathrm{NO}_{2}$ in the United States, Environ. Sci. Technol., 45, 4407-4414, doi:10.1021/es103578x, 2011.

O'Byrne, G., Martin, R. V., van Donkelaar, A., Joiner, J., and Celarier, E. A.: Surface reflectivity from the Ozone Monitoring Instrument using the Moderate Resolution Imaging Spectroradiometer to eliminate clouds: Effects of snow on ultraviolet and visible trace gas retrievals, J. Geophys. Res.-Atmos., 115, D17305, doi:10.1029/2009jd013079, 2010.

Ott, L. E., Pickering, K. E., Stenchikov, G. L., Allen, D. J., DeCaria, A. J., Ridley, B., Lin, R.-F., Lang, S., and Tao, W.K.: Production of lightning $\mathrm{NO}(\mathrm{x})$ and its vertical distribution calculated from three-dimensional cloud-scale chemical trans- 
port model simulations, J. Geophys. Res.-Atmos., 115, D04301, doi:10.1029/2009jd011880, 2010.

Palmer, P. I., Jacob, D. J., Chance, K., Martin, R. V., Spurr, R. J. D., Kurosu, T. P., Bey, I., Yantosca, R., Fiore, A., and Li, Q. B.: Air mass factor formulation for spectroscopic measurements from satellites: Application to formaldehyde retrievals from the Global Ozone Monitoring Experiment, J. Geophys. Res.-Atmos., 106, 14539-14550, doi:10.1029/2000jd900772, 2001.

Park, R. J., Jacob, D. J., Chin, M., and Martin, R. V.: Sources of carbonaceous aerosols over the United States and implications for natural visibility, J. Geophys. Res.-Atmos., 108, 4355, doi:10.1029/2002jd003190, 2003.

Park, R. J., Jacob, D. J., Field, B. D., Yantosca, R. M., and Chin, M.: Natural and transboundary pollution influences on sulfate-nitrate-ammonium aerosols in the United States: Implications for policy, J. Geophys. Res.-Atmos., 109, D15204, doi:10.1029/2003jd004473, 2004.

Park, R. J., Jacob, D. J., Kumar, N., and Yantosca, R. M.: Regional visibility statistics in the United States: Natural and transboundary pollution influences, and implications for the Regional Haze Rule, Atmos. Environ., 40, 5405-5423, doi:10.1016/j.atmosenv.2006.04.059, 2006.

Price, C., Penner, J., and Prather, M.: NOx from lightning, 1, Global distribution based on lightning physics, J. Geophys. Res., 102, 5929-5941, doi:10.1029/96JD03504, 1997.

Remer, L. A., Kleidman, R. G., Levy, R. C., Kaufman, Y. J., Tanre, D., Mattoo, S., Martins, J. V., Ichoku, C., Koren, I., Yu, H. B., and Holben, B. N.: Global aerosol climatology from the MODIS satellite sensors, J. Geophys. Res.-Atmos., 113, D14s07, doi:10.1029/2007jd009661, 2008.

Richter, A., Burrows, J. P., Nu“ $\beta$, H., Granier, C., and Niemeier, U.: Increase in tropospheric nitrogen dioxide over China observed from space, Nature, 437, 129-132, doi:10.1038/nature04092, 2005.

Rienecker, M. M., Suarez, M. J., Todling, R., Bacmeister, J., Takacs, L., Liu, H.-C., Gu, W., Sienkiewicz, M., Koster, R. D., Gelaro, R., Stajner, I., and Nielsen, E.: The GEOS-5 Data Assimilation System - Documentation of Versions 5.0.1, 9.1.0, and 5.2.0, NASA, 2008.

Rodgers, C. D.: Inverse Methods for Atmospheric Sounding: Theory and Practice, World Scientific Publishing, SingaporeNewJersey-London-Hong Kong, 2000.

Russell, A. R., Perring, A. E., Valin, L. C., Bucsela, E. J., Browne, E. C., Wooldridge, P. J., and Cohen, R. C.: A high spatial resolution retrieval of $\mathrm{NO}_{2}$ column densities from OMI: method and evaluation, Atmos. Chem. Phys., 11, 8543-8554, doi:10.5194/acp-11-8543-2011, 2011.

Sauvage, B., Martin, R. V., van Donkelaar, A., Liu, X., Chance, K., Jaeglé, L., Palmer, P. I., Wu, S., and Fu, T.-M.: Remote sensed and in situ constraints on processes affecting tropical tropospheric ozone, Atmos. Chem. Phys., 7, 815-838, doi:10.5194/acp-7-815-2007, 2007.

Sluis, W. W., Allaart, M. A. F., Piters, A. J. M., and Gast, L. F. L.: The development of a nitrogen dioxide sonde, Atmos. Meas. Tech., 3, 1753-1762, doi:10.5194/amt-3-1753-2010, 2010.

Sneep, M., de Haan, J. F., Stammes, P., Wang, P., Vanbauce, C., Joiner, J., Vasilkov, A. P., and Levelt, P. F.: Three-way comparison between OMI and PARASOL cloud pressure products, J. Geophys. Res.-Atmos., 113, D15s23, doi:10.1029/2007jd008694, 2008.

Spurr, R.: LIDORT and VLIDORT: Linearized pseudo-spherical scalar and vector discrete ordinate radiative transfer models for use in remote sensing retrieval problems, Light Scattering Reviews, edited by: Kokhanovsky, A., Springer, 2008.

van Donkelaar, A., Martin, R. V., Spurr, R. J. D., Drury, E., Remer, L. A., Levy, R. C., and Wang, J.: Optimal estimation for global ground-level fine particulate matter concentrations, J. Geophys. Res.-Atmos., 118, 5621-5636, doi:10.1002/jgrd.50479, 2013.

Vinken, G. C. M., Boersma, K. F., van Donkelaar, A., and Zhang, L.: Constraints on ship $\mathrm{NO}_{\mathrm{x}}$ emissions in Europe using GEOSChem and $\mathrm{OMI}$ satellite $\mathrm{NO}_{2}$ observations, Atmos. Chem. Phys. Discuss., 13, 19351-19388, doi:10.5194/acpd-13-19351-2013, 2013.

Walker, T. W., Martin, R. V., van Donkelaar, A., Leaitch, W. R., MacDonald, A. M., Anlauf, K. G., Cohen, R. C., Bertram, T. H., Huey, L. G., Avery, M. A., Weinheimer, A. J., Flocke, F. M., Tarasick, D. W., Thompson, A. M., Streets, D. G., and Liu, X.: TransPacific transport of reactive nitrogen and ozone to Canada during spring, Atmos. Chem. Phys., 10, 8353-8372, doi:10.5194/acp10-8353-2010, 2010.

Wang, J., Xu, X., Spurr, R., Wang, Y., and Drury, E.: Improved algorithm for MODIS satellite retrievals of aerosol optical thickness over land in dusty atmosphere: Implications for air quality monitoring in China, Remote Sens, Environ., 114, 2575-2583, doi:10.1016/j.rse.2010.05.034, 2010.

Wang, S. W., Zhang, Q., Streets, D. G., He, K. B., Martin, R. V., Lamsal, L. N., Chen, D., Lei, Y., and Lu, Z.: Growth in $\mathrm{NO}_{\mathrm{X}}$ emissions from power plants in China: bottom-up estimates and satellite observations, Atmos. Chem. Phys., 12, 4429-4447, doi:10.5194/acp-12-4429-2012, 2012.

Wang, X., Wang, Y., Hao, J., Kondo, Y., Irwin, M., Munger, J. W., and Zhao, Y.: Top-down estimate of China's black carbon emissions using surface observations: sensitivity to observation representativeness and transport model error, J. Geophys. Res., 118, 5781-5795, doi:10.1002/jgrd.50397, 2013.

Wang, Y., Jacob, D. J., and Logan, J. A.: Global simulation of tropospheric O3-NOx-hydrocarbon chemistry, 1. Model formulation, J. Geophys. Res., 103, 10713-10725, 1998.

Yang, F., Tan, J., Zhao, Q., Du, Z., He, K., Ma, Y., Duan, F., Chen, G., and Zhao, Q.: Characteristics of $\mathrm{PM}_{2.5}$ speciation in representative megacities and across China, Atmos. Chem. Phys., 11, 5207-5219, doi:10.5194/acp-11-5207-2011, 2011.

Yienger, J. J. and Levy, H.: Empirical model of global soil-biogenic NOx emissions, J. Geophys. Res., 100, 11447-11464, 1995.

Yu, H., Wang, P., Zong, X., Li, X., and Lue, D.: Change of $\mathrm{NO}_{2}$ column density over Beijing from satellite measurement during the Beijing 2008 Olympic Games, Chinese Science Bulletin, 55, 308-313, doi:10.1007/s11434-009-0375-0, 2010.

Zender, C. S., Bian, H. S., and Newman, D.: Mineral Dust Entrainment and Deposition (DEAD) model: Description and 1990s dust climatology, J. Geophys. Res.-Atmos., 108, 4416, doi:10.1029/2002jd002775, 2003.

Zhang, Q., Streets, D. G., Carmichael, G. R., He, K. B., Huo, H., Kannari, A., Klimont, Z., Park, I. S., Reddy, S., Fu, J. S., Chen, D., Duan, L., Lei, Y., Wang, L. T., and Yao, Z. L.: Asian emissions in 2006 for the NASA INTEX-B mission, Atmos. Chem. Phys., 9, 5131-5153, doi:10.5194/acp-9-5131-2009, 2009. 
Zhang, Q., He, K. B., and Huo, H.: Cleaning China's air, Nature, 484, 161-162, 2012.

Zhao, C. and Wang, Y. H.: Assimilated inversion of NOx emissions over east Asia using $\mathrm{OMI} \mathrm{NO}_{2}$ column measurements, Geophys. Res. Lett., 36, L06805, doi:10.1029/2008g1037123, 2009.

Zhou, Y., Brunner, D., Spurr, R. J. D., Boersma, K. F., Sneep, M., Popp, C., and Buchmann, B.: Accounting for surface reflectance anisotropy in satellite retrievals of tropospheric $\mathrm{NO}_{2}$, Atmos. Meas. Tech., 3, 1185-1203, doi:10.5194/amt-3-11852010, 2010.
Zhou, Y. P., Brunner, D., Hueglin, C., Henne, S., and Staehelin, J.: Changes in OMI tropospheric $\mathrm{NO}_{2}$ columns over Europe from 2004 to 2009 and the influence of meteorological variability, Atmos. Environ., 46, 482-495, doi:10.1016/j.atmosenv.2011.09.024, 2012. 